\title{
A systematic review of instruments for measuring outcomes in economic evaluation within aged care
}

\author{
Norma B. Bulamu*, Billingsley Kaambwa and Julie Ratcliffe
}

\begin{abstract}
Background: This paper describes the methods and results of a systematic review to identify instruments used to measure quality of life outcomes in older people. The primary focus of the review was to identify instruments suitable for application with older people within economic evaluations conducted in the aged care sector.

Methods: Online databases searched were PubMed, Medline, Scopus, and Web of Science, Psyclnfo, CINAHL, Embase and Informit. Studies that met the following criteria were included: 1) study population exclusively above 65 years of age 2) measured health status, health related quality of life or quality of life outcomes more broadly through use of an instrument developed for this purpose, 3) used a generic preference based instrument or an older person specific preference based or non-preference based instrument or both, and 4) published in journals in the English language after 2000.

Results: The most commonly applied generic preference based instrument in both the community and residential aged care context was the EuroQol - 5 Dimensions (EQ-5D), followed by the Adult Social Care Outcomes Toolkit (ASCOT) and the Health Utilities Index (HUI2/3). The most widely applied older person specific instrument was the ICEpop CAPability measure for Older people (ICECAP-O) in both community and residential aged care.

Conclusion: In the absence of an ideal instrument for incorporating into economic evaluations in the aged care sector, this review recommends the use of a generic preference based measure of health related quality of life such as the EQ-5D to obtain quality adjusted life years, in combination with an instrument that has a broader quality of life focus like the ASCOT, which was designed specifically for evaluating interventions in social care or the ICECAP-O, a capability measure for older people.
\end{abstract}

Keywords: Quality of life, Older people, Aged care, Preference-based instruments, Economic evaluation

\section{A systematic review of outcome measures for economic evaluation in aged care}

\section{Background}

In the year 2000, $11 \%$ (605 million) of the world's population was over 60 years of age and this figure is forecast to rise to $21 \%$ ( 2 billion persons) by 2050 [1]. The fastest growing cohort in this population is the oldest old (over 80 years of age) accounting for $14 \%$ of the older people population in 2014 and expected to increases to

\footnotetext{
* Correspondence: bula0011@flinders.edu.au

Flinders Health Economics Group, School of Medicine, Flinders University, A Block, Repatriation General Hospital, 202-16 Daws Road, Daw Park, SA 5041, Australia
}

over $19 \%$ by 2050 [1]. Older people currently represent the fastest growing age group in most developed countries and are major users of health and aged care services. Aged care services have an important role to play in enhancing the self-worth, independence and quality of life of older people [2,3]. The projected exponential increase in the prevalence of older people living in the community with cognitive decline, frailty and other comorbidities will inevitably contribute to a significant increase in the demand for, and utilization of aged care services in the future [1]. Most governments in developed countries subsidise different types of aged care services to enable older people to remain living at home including home care packages to support activities of daily living, 
nursing care, meals services, adult day care services, equipment and home adaptations, re-ablement services (to assist older people in recovering from and adapting to physical and mental illness) and support for people living with dementia [4-7].

In measuring the impact of service innovations in aged care, researchers in health economics and other disciplines are increasingly recognising that quality of life is a multidimensional concept and the impact of interventions for older people goes beyond health status, incorporating psychosocial and emotional well-being, independence, personal beliefs, material well-being and the external environment that influences development and activity [8-10]. Older people's interpretation of quality of life is based on their capability to achieve those things or participate in activities they value, viewing health as a resource to facilitate their participation in activities of daily living and social interactions [10-14]. The value they obtain from health care services and other interventions goes beyond physical functioning or the health dimensions, as measured by health related quality of life (HRQOL) instruments, to include non-health dimensions such as security in their physical environment, independence, sense of value and attachment, which are only captured by broader instruments $[15,16]$. It is therefore important that instruments used to measure and value quality of life outcomes in the aged care sector capture such broader quality of life outcomes.

Instruments for measuring health status and/or quality of life may be differentiated into preference based and non-preference based. Preference based instruments typically incorporate scoring algorithms which are based upon the preferences of a general population sample for the health and/or quality of life states defined by the instrument elicited using one or more valuation methods such as the visual analogue scale (VAS), time trade off (TTO), standard gamble (SG) and discrete choice experiments (DCE) [17, 18]. Preference based instruments are typically used by health economists and health service researchers within economic evaluations in a cost utility analysis framework (CUA) where the main measure of outcome is quality adjusted life years (QALYs). Nonpreference based instruments are not suitable for application in CUA because they do not facilitate the calculation of QALYs. Table 1 summarises some of the most popular generic preference based and generic nonpreference based instruments.

In contrast to generic preference based instruments, condition specific and population specific preference based instruments focus upon one condition or disease area or population of interest. Population specific preference based instruments have been designed to be utilised with a single population group e.g. children or older people. Examples of population specific preference based instruments include the Adult Social Care Outcomes Toolkit (ASCOT) [19, 20] designed to measure quality of life for individuals receiving social care and the older person specific ICEpop CAPability measure for Older people (ICECAP-O), a measure of capability [12]. Table 2 summarises some of the most popular older person specific instruments.

This paper describes the methods and results of a systematic review to identify instruments that have been used in measuring quality of life outcomes in older people and documents the contexts in which the instruments have been applied. The primary focus is on instruments suitable for application within a CUA in the aged care sector. The findings from this review will be utilised to inform the design of economic evaluations in community aged care service delivery in Australia. The findings also have wider applicability internationally for researchers designing and conducting economic evaluations with dependent older people in determining the most suitable instruments for application in the aged care sector.

The focus on older-people-specific outcomes is motivated by assertions in the literature that economic evaluations of interventions aimed at older people should be conducted using outcome measures tailored towards meeting the goals of services consumed by older people [16]. Research also indicates that such measures need to capture broader quality of life outcomes such as affection and control that extend beyond health related quality of life whilst also recognising that many older people view health as a resource to facilitate their participation in activities of daily living and social interactions [10, 11, 15]. Different age groups of the population have also been reported to prioritize different areas of life as important, with older people being the most likely to prioritize their health and ability to get out while younger people are more likely to prioritize work, finances, having chances to learn new skills and their sex lives [21-23].

A recent systematic review conducted by Makai and colleagues [15] identified instruments suitable for applications in economic evaluations of interventions in older people receiving long term care. This systematic review builds upon the work previously conducted in two main ways; firstly by capturing the three year period beyond their systematic review and secondly by focusing in more detail upon the particular contexts in which the instrument/s were applied.

Capturing information on and gaining insights into the context within which instruments have been previously applied is particularly relevant in guiding the selection of the most appropriate instrument/s for application within economic evaluation in the aged care sector [24]. Some quality of life instruments have been specifically developed for use within certain settings. For instance, the developers of the ASCOT originally designed the instrument to 
Table 1 Generic preference based and non-preference based instruments

\begin{tabular}{|c|c|c|c|c|}
\hline Instrument & Dimensions & Levels & Valuation & Source of preference weights \\
\hline \multicolumn{5}{|c|}{ Generic preference based instruments } \\
\hline $\begin{array}{l}\text { EuroQol - } 5 \text { Dimensions } \\
(E Q-5 D)^{a}\end{array}$ & $\begin{array}{l}\text { Mobility, self-care, usual activities, pain/ } \\
\text { discomfort and anxiety/depression [97] }\end{array}$ & $3-5$ & TTO and VAS & $\begin{array}{l}\text { Adult general population samples from a } \\
\text { number of countries including Australia, } \\
\text { UK, USA, Spain, Netherlands, Denmark, } \\
\text { France, Germany, Japan, Thailand and } \\
\text { Zimbabwe }\end{array}$ \\
\hline $\begin{array}{l}\text { Health Utilities Index } \\
\text { Mark2 (HUI2) }\end{array}$ & $\begin{array}{l}\text { Sensation, mobility, emotion, cognition, } \\
\text { self-care, pain and fertility [98] }\end{array}$ & $3-5$ & VAS and SG & \multirow{2}{*}{$\begin{array}{l}\text { Canada (age groups 5-37, 12-16, 8-16), } \\
\text { USA (18-89), Australia (15+), UK (general } \\
\text { population) and Uruguay (8-17 age group }\end{array}$} \\
\hline $\begin{array}{l}\text { Health Utilities Index } \\
\text { Mark3 (HUI3) }\end{array}$ & $\begin{array}{l}\text { Vision, hearing, speech, ambulation, } \\
\text { dexterity, emotion, cognition and } \\
\text { pain [98] }\end{array}$ & $5-6$ & VAS & \\
\hline $\begin{array}{l}\text { Short Form } 6 \text { Dimensions } \\
\text { (SF-6D) }\end{array}$ & $\begin{array}{l}\text { Physical functioning, role limitation, } \\
\text { social functioning, pain, mental health } \\
\text { and vitality [99] }\end{array}$ & $4-6$ & SG & $\begin{array}{l}\text { Adult general population samples from } \\
\text { UK, Japan, Hong Kong, Australia, Brazil }\end{array}$ \\
\hline 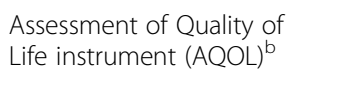 & $\begin{array}{l}\text { Independent living, happiness, } \\
\text { mental health, coping, relationships, } \\
\text { self-worth, pain and senses [100] }\end{array}$ & $4-6$ & TTO & $\begin{array}{l}\text { Australia (adult general population } \\
\text { sample) }\end{array}$ \\
\hline $\begin{array}{l}\text { Quality of Wellbeing } \\
\text { scale (QWB) }\end{array}$ & $\begin{array}{l}\text { Mobility, physical activity and social } \\
\text { activity [101] }\end{array}$ & Multi-level & VAS & USA (adult general population sample) \\
\hline 15-Dimensions (15D) & $\begin{array}{l}\text { Health-mobility, vision, hearing, breathing, } \\
\text { sleeping, eating, speech, elimination, } \\
\text { usual activities, mental function, discomfort } \\
\text { and symptoms, depression, distress, } \\
\text { vitality and sexual activity [102] }\end{array}$ & $4-5$ & VAS & $\begin{array}{l}\text { Finland (adult general population } \\
\text { sample) }\end{array}$ \\
\hline $\begin{array}{l}\text { Adult Social Care Outcomes } \\
\text { Toolkit (ASCOT) }\end{array}$ & $\begin{array}{l}\text { Personal cleanliness and comfort, } \\
\text { Accommodation cleanliness and comfort, } \\
\text { Food and drink, Safety, Social participation } \\
\text { and involvement, Occupation, Control over } \\
\text { daily life and Dignity }[19,20]\end{array}$ & 3 & BWS and TTO & UK (adult general population sample) \\
\hline \multicolumn{5}{|c|}{ Generic non-preference based instruments } \\
\hline Short Form 36 (SF-36) & $\begin{array}{l}8 \text { attributes; physical functioning ( } 10 \text { items), } \\
\text { Role - physical ( } 4 \text { items), Bodily pain ( } 2 \text { items), } \\
\text { General health ( } 5 \text { items), Vitality ( } 4 \text { items), } \\
\text { Social functioning ( } 2 \text { items), Role - emotional } \\
\text { ( } 3 \text { items) and Mental health ( } 5 \text { items) [103] }\end{array}$ & $2-6$ & N/A & N/A \\
\hline Short Form 12 (SF-12) & $\begin{array}{l}\text { Physical functioning ( } 2 \text { items), role limitations } \\
(2 \text { items), bodily pain ( } 1 \text { item), general health } \\
\text { perceptions ( } 1 \text { item), vitality }(1 \text { item), social } \\
\text { functioning ( } 1 \text { item), role limitations because } \\
\text { of emotional problems ( } 2 \text { items), general mental } \\
\text { health or psychological distress and psychological } \\
\text { well-being ( } 2 \text { items) [103] }\end{array}$ & $3-6$ & N/A & N/A \\
\hline $\begin{array}{l}\text { World Health Organisation } \\
\text { Quality of Life brief instrument } \\
\text { (WHOQoL-Bref) }\end{array}$ & $\begin{array}{l}\text { Physical characteristics, Psychological aspects, } \\
\text { Social relationships and Environmental } \\
\text { circumstances [104] }\end{array}$ & 6 & N/A & N/A \\
\hline $\begin{array}{l}\text { Nottingham Health } \\
\text { Profile (NHP) }\end{array}$ & $\begin{array}{l}\text { Health; energy, pain, emotional reactions, sleep, } \\
\text { social isolation, and physical mobility and } \\
\text { General life; occupation, housework, social life, } \\
\text { family life, sexual function, hobbies and } \\
\text { holidays [105] }\end{array}$ & 2 & N/A & N/A \\
\hline
\end{tabular}

\footnotetext{
${ }^{\mathrm{a}} \mathrm{A}$ new 5 level version of the EQ-5D was launched in January 2014 [106]

${ }^{b}$ Four instruments based on the number of dimensions: AQOL-4D, -6D, -7D and -8D [100]

'Other versions of ASCOT are SCT4 (a four-level self-report version for use in community settings), INT4 (a four-level interview version used in community settings)
} and the $\mathrm{CH} 3$ (a three-level rating schedule based on observation and interviews used in communal living settings) [20]

capture information about an individual's social-carerelated quality of life within community and residential settings [19]. It could also be argued that health-related quality of life instruments such as the EuroQoL 5 dimensions (EQ-5D) are more suitable for individuals receiving health-focussed interventions such as those in hospital where the primary objective is the maintenance of or improvement in health. There is evidence to indicate 
Table 2 Older people specific instruments

\begin{tabular}{|c|c|c|c|}
\hline Instrument & Dimensions & Levels & Scoring algorithm \\
\hline \multicolumn{4}{|l|}{ Preference based } \\
\hline ICEpop CAPability measure for Older people (ICECAP-O) & Attachment, Security, Role, Enjoyment and Control [92] & 4 & UK \\
\hline \multicolumn{4}{|l|}{ Non-preference based } \\
\hline Older People's Quality of Life (OPQOL) ${ }^{a}$ & $\begin{array}{l}\text { Life overall, health, social relationships and participation, } \\
\text { independence, control over life, freedom, and area: home } \\
\text { and neighbourhood, psychological and emotional wellbeing, } \\
\text { financial circumstances, and religion/culture [89] }\end{array}$ & 5 & N/A \\
\hline Control Autonomy Self-realization and Pleasure (CASP 19) & Control, Autonomy, Self-realization and Pleasure [107] & 4 & N/A \\
\hline $\begin{array}{l}\text { World Health Organisation Quality of Life Instrument-Older } \\
\text { Adults Module (WHOQoL-Old) })^{\mathrm{b}}\end{array}$ & $\begin{array}{l}\text { Sensory functioning, autonomy, past-present-future activities, } \\
\text { social participation, death and intimacy [108] }\end{array}$ & 5 & N/A \\
\hline
\end{tabular}

${ }^{\mathrm{a} A}$ shorter 13 item version the OPQOL-Brief has been developed

${ }^{\mathrm{b}}$ Three shorter versions of the WHOQoL-Old have been developed, each having only 6 items, one item per domain, as opposed to the original 24 items

that there are differences in quality of life perceptions between hospitalised/ambulatory and non-hospitalised older adults [23]. Fassino et al. [25] also showed that aspects of quality of life that matter to dependent older people (individuals dependent on others for their day-to-day living) differ from those that matter to independent older people and a study by Bowling et al. [26] found that better functional ability was related to better quality of life in older age. Bowling et al. [27] also postulated that the multifaceted nature of independence, particularly in older age, is mostly ignored in the wider quality of life measurement literature.

In this study, therefore, we sought to assess whether quality of life instrument use differed according to context, which was defined by the location or setting in which services for older people were being provided, i.e. in the community, residential facilities or within a hospital and according to the level of dependency for older people living in the community (specifically whether the study population was made up of dependent or independent older people). For the purposes of this review, dependency was defined as frailty or individuals dependent in activities of daily living as assessed by instruments such as the Barthel index and individuals who required or lived with an informal carer such as older people with cognitive impairment and those who have experienced or are recovering from stroke. Studies where majority of the study population was comprised of dependent older people were classified under the dependent heading.

Therefore, this paper seeks to provide arguments for the suitability (or otherwise) of the different instruments in economic evaluations of interventions for older people in various contexts within the aged care sector.

Specifically, the three main objectives of the review were:

- To identify instruments used in the published literature to measure quality of life outcomes for older people
- To identify the different contexts in which the instruments have been used

- To provide arguments for the appropriateness and suitability of the different quality of life instruments within a cost utility analysis (CUA) framework of service delivery innovations in aged care.

\section{Review}

\section{Methods}

The key search questions to be answered by this review were consistent with the three main objectives previously specified. The review process was consistent with the PRISMA guidelines for the conduct of systematic reviews [28].

\section{Databases}

PubMed, Medline, CINAHL, Scopus, and Embase, PsycInfo, informit and Web of science.

\section{Search terms}

Keywords were replicated based on the review undertaken by Makai et al. [15] with the addition of two more concepts (instruments and the contexts in which quality of life was measured) as well as appropriate subject headings and keywords based on the objectives of this review. Five major concepts were applied in this search; quality of life, the population (older people aged 65 years and over), validity, instruments and study contexts defined as community aged care or residential aged care. These concepts were combined with the 'AND' operator. The full search strategy, including subject headings and key words, used in Medline is attached in Additional file 1. The same broad strategy was replicated in other databases with appropriate adjustments made to align the strategy to the requirements of these other databases.

\section{Selection criteria}

Studies that met the following criteria were considered: 1) measured quality of life and/or health status and/or 
health related quality of life as a primary or secondary outcome, either as a snapshot/cross-sectional or longitudinally over time in aged care settings, 2) used a generic or older person specific preference based instrument or a non-preference based older person specific quality of life instrument or both 3) study population was exclusively 65 years and over, dependent older people living in the community or in residential aged care facilities, and 4) published in peer reviewed journals in the English language between 2000 and July 2015 .

Studies were excluded if 1) study population was not exclusive to people aged 65 years and over 2) study population was focused primarily upon patients in the health system and/or not comprised of dependent older people living in the community or in residential aged care facilities 3) only disease specific or generic nonpreference based measures of quality of life/health related quality of life were used and studies in which quality of life was not measured using an instrument or they used questionnaires specifically designed for the study,
4) dissertations, commentaries, conference papers or review articles and studies for which the full text article could not be obtained.

To assess the reliability of the study selection process, selection was performed by all three authors on a random sample of $5 \%$ of the studies by using the selection criteria described above. The overall agreement was then calculated using Cohen's kappa statistic [26].

\section{Results}

\section{Study selection process}

Figure 1 presents the study selection process which was divided into four key stages:

i) Identification: In July 2015, 9545 studies were identified from the online databases and an additional 337 studies from backward/forward searches and basic internet search using the key words. 4969 studies were eliminated because they were found to be duplicates.

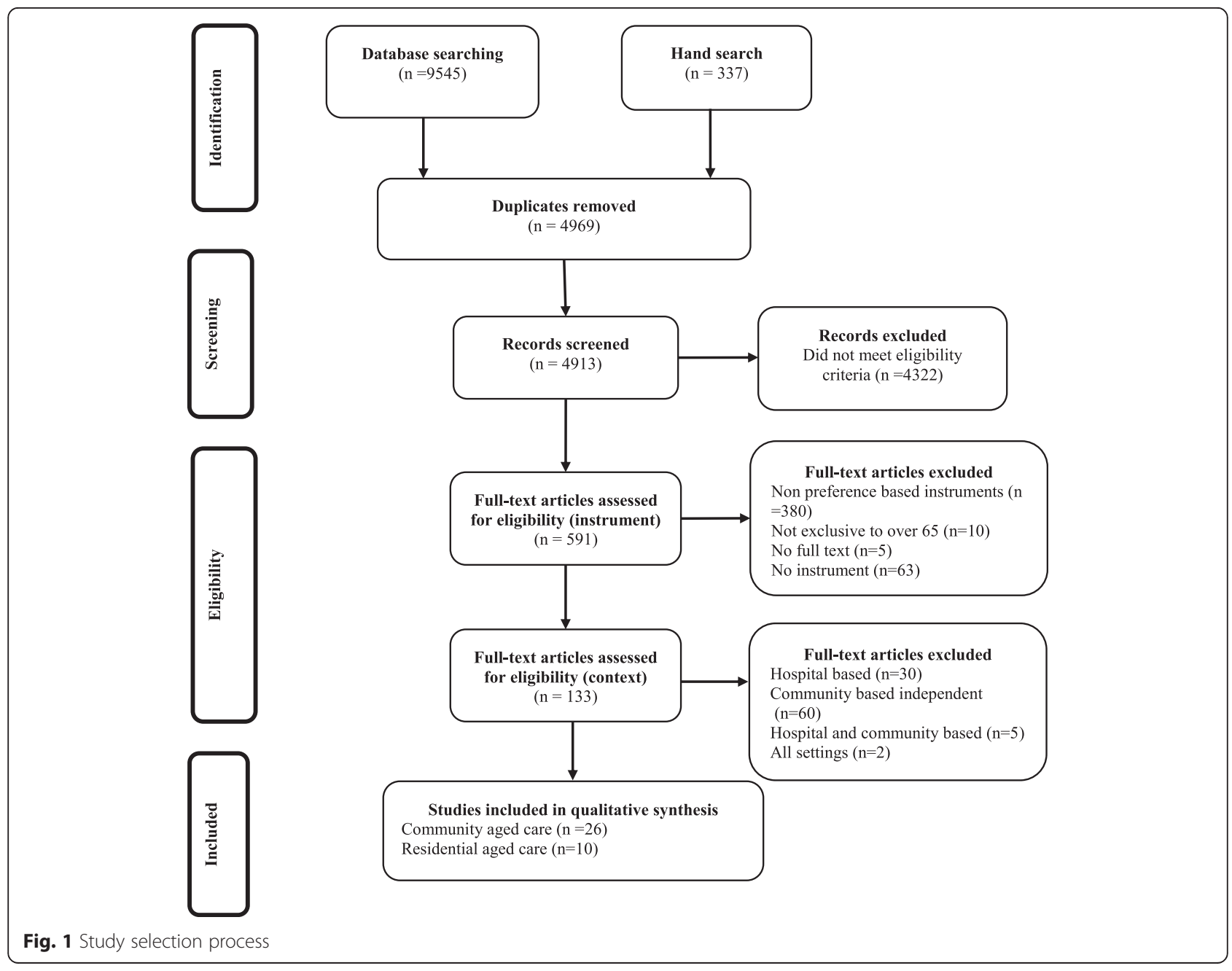


ii) Screening: 4913 titles and abstracts were screened for eligibility. 4322 studies were excluded as they did not meet the eligibility criteria.

iii) Eligibility: 591 full texts articles were assessed at this stage. All three authors independently assessed $5 \%$ of the identified studies and overall agreement was then calculated using Cohen's kappa statistic [28] 380 studies were excluded because they measured quality of life using generic non-preference based instruments while 63 studies used questionnaires specifically designed for the study, the study population in 10 studies was not exclusive to people over 65 years of age and the full text articles could not be obtained for five studies. A further 97 studies were eliminated whose study population was focused primarily upon patients in the health system and/or not comprised of dependent older people living in the community or in residential aged care facilities.

iv) Included: 36 studies were considered in the qualitative synthesis; 26 studies undertaken among dependent older people receiving community aged care services and 10 studies among those residing in aged care facilities. The chance-corrected agreement between the abstracts selected by the primary author and the two co-authors was in the range of 0.77 and 0.88 , with an average kappa statistic of 0.81 , which was substantial/almost perfect [29].

\section{Key finding 1: study characteristics}

Full reports of the included studies were read to extract information relating to the population and country of the research, sample size and type of study, the instrument used and the context in which the instrument/s were applied. Details of all the studies assessed for eligibility and classified by context in this review are provided in Table 3.

Geographically studies were conducted in several countries; 7 (19 \%) from the Netherlands, 6 studies (16\%) each from the UK and Canada, 5 studies (14\%) from the USA(with one study from both USA and Canada) while three studies each $(8 \%)$ were from Australia and Italy. 2 studies (5\%) were conducted in Sweden and one study (3\%) each in Poland, Germany, Denmark, Japan and Turkey. The majority of studies (59 \%) were undertaken in Europe. Figure 2 is a summary of the geographical distribution of the included studies.

Twenty two studies (61\%) were undertaken using a cross-sectional design, 8 (22\%) randomised control trials, 3 (8\%) prospective cohort studies, 2 (6\%) longitudinal studies and one explorative qualitative study.

The sample sizes varied substantially from a minimum of 10 to a maximum of 29,935 older people. Figure 3 summarises the sample size distributions of included studies.

\section{Key finding 2: contexts and settings}

The identified studies were grouped into four contexts; community based dependent, community based independent, residential facility based and hospital based older people (see Table 3). Two contexts were considered to be reflective of older people receiving aged care services; community based dependent older people and older people based in residential aged care facilities. The results reported below therefore relate to these two contexts:

a. Community living dependent older people: Twenty six studies were identified; seven studies conducted in older people with no particular prevailing condition [30-36], ten studies among older people with cognitive impairment [37-46] while seven studies comprised of frail older people where cognitive status was unspecified [24, 47-52]. One study each was among older people with depression [53] and those with a previous stroke [54].

b. Residential aged care context: Ten studies were identified in this context; three among residents with cognitive impairment [55-57], two studies among frail older residents where cognitive status was unspecified $[58,59]$ and four studies recruited samples from the general resident population who had no cognitive impairment and were not too ill to participate in the study [60-63] while one study specifically considered residents with depression [64].

Key finding 3: instruments used to measure quality of life Table 4 summarises the instruments that have been used to date to measure quality of life within the community and residential aged care context and Table 5 reports the frequency with which they were used.

In general, the most commonly applied generic preference based instrument was the EQ-5D (51\%) followed by the ASCOT (16\%), and the most widely applied older person specific instrument was the ICECAP-O (11\%) (Table 5). In the community aged care context, the most applied generic instrument was the EQ-5D $(n=16)$ followed by the ASCOT $(n=6)$ and HUI3 $(n=5)$ and the older people specific ICECAP-O $(n=3)$. Other instruments applied in this sector were the older people specific OPQOL $(n=2)$ and CASP-19 $(n=1)$ and the generic QWB $(n=1)$. In the residential aged care context on the other hand, the most widely applied instrument was the EQ-5D $(n=7)$ followed by the ICECAP-O $(\mathrm{n}=2)$. Other instruments applied were the ASCOT $(n=1)$ and the older people specific WHOQoL-Old $(\mathrm{n}=1)$.

The popularity of the EQ-5D may be attributed to several reasons including its brevity, the availability of various 
Table 3 Classification of studies by context

\begin{tabular}{lll}
\hline Title & Population & Instruments used \\
\hline $\begin{array}{l}\text { Community-based dependent older people } \\
\text { Ability to perform activities of daily living is the }\end{array}$ & Denmark & EQ-5D \\
$\begin{array}{l}\text { main factor affecting quality of life in patients } \\
\text { with dementia [37] }\end{array}$ & $\mathrm{N}=244$ & \\
$\begin{array}{l}\text { An assessment of the construct validity of the } \\
\begin{array}{l}\text { ASCOT measure of social care-related quality } \\
\text { of life with older people [30] }\end{array}\end{array}$ & $\mathrm{N}=301$ & ASCOT \\
& & \\
$\begin{array}{l}\text { Comorbid psychosocial symptoms and quality } \\
\text { of life in patients with dementia [38] }\end{array}$ & USA & EQ-5D (patient \\
& $\mathrm{N}=89$ pairs & and proxy)
\end{tabular}

Comparing measurement properties of the EQ-5D-3 L, ICECAP-O and ASCOT in frail older people [24]

Netherlands

EQ-5D

$N=190$

ICECAP-O

ASCOT

Day care centre attendance and quality of life in depressed older adults living in the community [53]

Italy

EQ-5D

$N=149$

Depressive symptoms and cognitive status affect health-related quality of life in older patients with Parkinson's disease [39]

USA

EQ-5D

$N=101$

Dimensions and correlates of quality of life according to frailty status: a cross-sectional study on community-dwelling older adults referred to an outpatient geriatric service in Italy [47]

Dutch translation and cross-cultural validation of the Adult Social Care Outcomes Toolkit (ASCOT) [48]

Netherlands

ASCOT

$N=190$

Netherlands

EQ-5D

Exploration of the content validity and feasibility of the EQ-5D-3 L, ICECAP-O and ASCOT in older adults [49]

$N=10$

ICECAP-O

ASCOT

Sweden

Factors Related to Performance-Based

$N=195$

Mobility and Self-reported Physical Activity in Individuals 1-3 Years after Stroke: A Cross-sectiona Cohort Study [54]

Health utility scores in Alzheimer's disease:

Canada differences based on calculation with American and Canadian preference weights [40]

$N=216$

Health-related quality of life in Parkinson disease: correlation between Health Utilities Index III and Unified Parkinson's Disease Rating Scale (UPDRS) in U.S. male veterans [41]

Loneliness and Quality of Life in Chronically III Rural Older Adults [50]

Measuring health status and decline in at-risk seniors residing in the community using the Health Utilities Index Mark 2 [51]

$\mathrm{N}=60$

Canada

$N=192$
Main findings

Dependency upon others to perform ADL was the main factor affecting HRQL

This study provides some evidence for the construct validity of the ASCOT attributes and therefore support for ASCOT's use in economic evaluation and demonstrated the feasibility of its use among older people

Authors discuss the psychometric and conceptual implications of possible differences between self- and other-ratings of quality of life, and treatment implications for caregivereducation interventions

Our findings support the adoption of ICECAP-O and ASCOT as outcome measures in economic evaluations of care interventions for older adults that have a broader aim than health-related QOL

Therefore, in older outpatients suffering from a depressive disorder without dementia the attendance of a DC was an independent correlate of the quality of life

Patients with PD had significantly higher (worse) GDS scores than matched controls and were more likely to take antidepressant medication

Five of the seven dimensions of quality of life were negatively affected by frailty, but only one SOF criterion for frailty (reduced energy level) was independently related to quality of life after correction for age, functional status and depression

This study provides preliminary evidence that the Dutch translation of the ASCOT is valid, reliable and comparable to the original English version

Researchers who intend to use the EQ-5D, ICECAP-O or ASCOT in economic evaluations of care services for older adults, should be aware of the response issues that occur during the administration of these measures

Individuals perceived disabilities that are partly potentially modifiable 1-3 years after stroke

In $\mathrm{AD}$ studies, researchers should calculate health utility scores by using preference weights obtained in the general population of their country of interest

Poor self-care in PD reflected by worsening UPDRS-II scores is strongly correlated with low generic HRQL

Nurses should assess for loneliness as part of their comprehensive assessment of patients with chronic illness
The HUI2 measure of HRQL in older persons at risk for institutionalization appears to reflect health status at a point in time and to be responsive to changes in health status over time 
Table 3 Classification of studies by context (Continued)

\begin{tabular}{|c|c|c|}
\hline \multirow[t]{2}{*}{ Measuring the outcomes of long-term care [31] } & UK & ASCOT \\
\hline & $N=224$ & $E Q-5 D$ \\
\hline \multirow{2}{*}{$\begin{array}{l}\text { Older People's Quality of Life (OPQOL) scores } \\
\text { and adverse health outcomes at a one-year } \\
\text { follow-up. A prospective cohort study on older } \\
\text { outpatients living in the community in Italy [52] }\end{array}$} & Italy & OPQOL \\
\hline & $N=239$ & \\
\hline \multirow{4}{*}{$\begin{array}{l}\text { Predictors of Family Caregiver Ratings of Patient } \\
\text { Quality of Life in Alzheimer Disease: Cross-Sectional } \\
\text { Results from the Canadian Alzheimer's Disease } \\
\text { Quality of Life Study [42] }\end{array}$} & Canada & EQ-5D \\
\hline & $N=412$ & QWB \\
\hline & & HUI3 \\
\hline & & SF-36 \\
\hline \multirow{2}{*}{$\begin{array}{l}\text { Predictors of Patient Self-Ratings of Quality of } \\
\text { Life in Alzheimer Disease: Cross-Sectional } \\
\text { Results From the Canadian Alzheimer's Disease } \\
\text { Quality of Life Study [43] }\end{array}$} & Canada & EQ-5D \\
\hline & $N=370$ & QWB \\
\hline \multirow{2}{*}{$\begin{array}{l}\text { Predictors of quality of life in older people living } \\
\text { at home and in institutions [32] }\end{array}$} & Poland & EQ-5D \\
\hline & $N=312$ & \\
\hline \multirow{2}{*}{$\begin{array}{l}\text { Psychometric properties of the EQ-5D in a study } \\
\text { of people with mild to moderate dementia [44] }\end{array}$} & Germany & EQ-5D \\
\hline & $N=390$ & \\
\hline \multirow{2}{*}{$\begin{array}{l}\text { Responsiveness and construct validity of the } \\
\text { health utilities index in patients with } \\
\text { dementia [45] }\end{array}$} & USA & HUI3 \\
\hline & $N=408$ & (proxy completed) \\
\hline \multirow{2}{*}{$\begin{array}{l}\text { Sex differences in the relative contribution of } \\
\text { social and clinical factors to the Health Utilities } \\
\text { Index Mark } 2 \text { measure of health-related quality } \\
\text { of life in older home care clients [33] }\end{array}$} & Canada and USA & HUI2 \\
\hline & $N=514$ & \\
\hline \multirow{2}{*}{$\begin{array}{l}\text { Telephone reliability of the French Activity } \\
\text { Index and EQ-5D amongst older adults [34] }\end{array}$} & Australia & EQ-5D \\
\hline & $N=53$ & \\
\hline
\end{tabular}

The results support our hypothesis that ASCOT has greater construct validity in this case

In an older outpatient population in Italy the OPQOL total score and its health-related sub-score were independent predictors of several adverse health outcomes at one year

Caregiver ratings of patient function and depression were consistent independent predictors of caregiver-rated quality of life, using a spectrum of quality of life measures, while measures of patient cognition and caregiver burden and depression were not

Self-rated symptoms of depression were a consistent independent predictor of patient-rated quality of life across diverse quality of life measures, while performancebased measures of cognition and informantbased functional status were not

The relative contribution of functional and medical comorbidities, as well as health-promoting behaviors to quality of life, may be different in community-dwelling and institutionalized elders

The study showed that the EQ-5D is especially applicable to patients with mild dementia and their caregivers as proxies

Our results support the construct validity of the proxy-rated HUI2/3 in patients with moderate to severe dementia. The proxy-rated HUI should be used in patients with moderate to severe dementia, but the self-rated HUI may be appropriate for subjects with milder cognitive impairment

For females and males, HRQL scores were negatively associated with conditions predictive or indicative of disability and with markers of psychosocial stress

Telephone administration of the FAI and EQ-5D instruments provides comparable results to face-to-face administration amongst older adults deemed to have cognitive functioning intact at a basic level, indicating that this is a suitable alternate approach for collection of this information

Netherlands

$N=296$

ICECAP-O

EQ-5D Netherlands [35]

Validation study of the prototype of a disease-specific index measure for health-related quality of life in dementia [46]

What can local authorities do to improve the social care-related quality of life of older adults living at home? Evidence from the Adult Social Care Survey [36]
Netherlands

EQ-5D

$\mathrm{N}=145$

UK
The ICECAP-O seems to be a valid instrument of capability-wellbeing in older, post-hospitalized people, showing good convergent validity with health and wellbeing instruments, and is able to discriminate between elderly with various health profiles

The DQI prototype proved valid and feasible for patients and caregivers and is appropriate for very mild to moderate dementia

SCRQoL is significantly lower for older adults who find it more difficult to find information and advice, for those who report that their home design is inappropriate for their needs and for those who find it more difficult to get around their local area 
Table 3 Classification of studies by context (Continued)

\begin{tabular}{|c|c|c|}
\hline \multicolumn{3}{|l|}{ Residential facility-based older people } \\
\hline \multirow{2}{*}{$\begin{array}{l}\text { Capabilities and quality of life in Dutch } \\
\text { psycho-geriatric nursing homes: an exploratory } \\
\text { study using a proxy version of the ICECAP-O [55] }\end{array}$} & Netherlands & ICECAP-O \\
\hline & $N=122$ & $E Q-5 D$ \\
\hline \multirow{2}{*}{$\begin{array}{l}\text { Determinants of health-related quality of life in } \\
\text { institutionalized older persons in northern } \\
\text { Sydney [58] }\end{array}$} & Australia & \multirow[t]{2}{*}{ EQ-5D } \\
\hline & $N=612$ & \\
\hline \multirow{2}{*}{$\begin{array}{l}\text { Effects of cognitive stimulation therapy Japanese } \\
\text { version (CST-J) for people with dementia: A } \\
\text { single-blind, controlled clinical trial [56] }\end{array}$} & Japan & \multirow[t]{2}{*}{ EQ-5D } \\
\hline & $N=56$ & \\
\hline \multirow{2}{*}{$\begin{array}{l}\text { Exercise for depression in care home residents: } \\
\text { a randomised controlled trial with } \\
\text { cost-effectiveness analysis (OPERA) [64] }\end{array}$} & UK & \multirow[t]{2}{*}{$E Q-5 D$} \\
\hline & $N=1054$ & \\
\hline \multirow{2}{*}{$\begin{array}{l}\text { Performance of the EQ-5D and the EQ-5D }+C \\
\text { in elderly patients with cognitive impairments [57] }\end{array}$} & Netherlands & \multirow[t]{2}{*}{$E Q-5 D$} \\
\hline & $N=196$ & \\
\hline \multirow{2}{*}{$\begin{array}{l}\text { Quality of life of older frail persons receiving a } \\
\text { post-discharge program [59] }\end{array}$} & Australia & ICECAP-O \\
\hline & $N=351$ & $E Q-5 D$ \\
\hline \multirow{2}{*}{$\begin{array}{l}\text { Quality of life outcomes for residents and } \\
\text { quality ratings of care homes: is there a } \\
\text { relationship? [60] }\end{array}$} & UK & \multirow[t]{2}{*}{ ASCOT } \\
\hline & $N=366$ & \\
\hline
\end{tabular}

Quality of life and attitudes to ageing in Turkish older adults at old people's homes [61]

Strategies to implement community guidelines on nutrition and their long tern clinical effects in nursing home residents [62]

The agreement between proxy and self-completed EQ-5D for care home residents was better for index scores than individual domains [63]

$$
\mathrm{N}=565 \text { pairs }
$$

EQ-5D (proxy respondent)

Community based independent older people

A comparison of the ICECAP-O with EQ-5D in a falls prevention clinical setting: are they complements or substitutes? [11]

A concise alternative for researching health-related quality of life in older people [109]

A cross-sectional study of quality of life in an elderly population ( 75 years and over) with atrial fibrillation: secondary analysis of data from the Birmingham Atrial Fibrillation Treatment of the Aged study [110]

A measure of quality of life in early old age: The theory, development and properties of a needs satisfaction model (CASP-19) [107]

\section{Turkey}

$N=120$

Sweden

$N=101$
WHOQoL-Old

EQ-5D
ICECAP-O

$$
N=1762
$$

UK
ICECAP-O measures a more general concept than health-related quality of life and can differentiate between restrained and non-restrained psycho-geriatric clients

Common health states that may cause loss of independence and dignity are strongly, and independently, associated with the HRQL of institutionalized older persons

The CST-J shows promising improvements in cognition, mood, and aspects of quality of life for people with dementia in Japanese care settings

The results do not support the use of a whole-home physical activity and moderate-intensity exercise programme to reduce depression in care home residents

We conclude that the EQ-5D performs well for evaluating HRQL in a population with cognitive impairments

The type and intensity of programs offered to older frail people post hospital admission can impact on their recovery and quality of life gains

The approach to providing quality ratings by the regulator in England is currently under review. Future quality indicators need to demonstrate their relationship with quality of life outcomes if they are to be a reliable guide to commissioners and private individuals purchasing care

The results indicated that there was significant relationship between $\mathrm{QOL}$ and attitudes to ageing of older adults

An extended model of implementation of nutritional guidelines, including guidance and feedback to NH staff, did not affect nutritional status but may be associated with a delayed cognitive decline in communicative $\mathrm{NH}$ residents

Proxies appear to be an acceptable source of data for index scores and QALYs but may be less reliable if individual domains are considered

Our study suggests that the EQ-5D and ICECAP-O provide complementary information

The EQ-5D may provide a valid measure of health-related quality of life in a cross-sectional population sample of older adults, although the emphasis of the scale is very much on physical health and functioning

In the absence of co-morbidity, chronic AF has little impact on generic quality of life in an elderly non-acutely ill population

The CASP-19 appears to be a useful scale for measuring quality of life in older people 
Table 3 Classification of studies by context (Continued)

\begin{tabular}{|c|c|c|}
\hline $\begin{array}{l}\text { A short measure of quality of life in older age: } \\
\text { the performance of the brief Older People's } \\
\text { Quality of Life questionnaire (OPQOL-brief) [111] }\end{array}$ & $\begin{array}{l}\text { UK } \\
N=589\end{array}$ & $\begin{array}{l}\text { OPQOL, CAS } \\
\text { and the } \\
\text { WHOQOL-O }\end{array}$ \\
\hline $\begin{array}{l}\text { An assessment of the construct validity of the } \\
\text { descriptive system for the ICECAP capability } \\
\text { measure for older people [16] }\end{array}$ & $\begin{array}{l}\text { UK } \\
N=315\end{array}$ & ICECAP-O \\
\hline $\begin{array}{l}\text { An assessment of the relationship between } \\
\text { informal caring and quality of life in older } \\
\text { community-dwelling adults - more positives } \\
\text { than negatives? [112] }\end{array}$ & $\begin{array}{l}\text { Australia } \\
\mathrm{N}=786\end{array}$ & ICECAP-O \\
\hline $\begin{array}{l}\text { Assessing Quality of Life among British Older } \\
\text { People Using the ICEPOP CAPability (ICECAP-O) } \\
\text { Measure [92] }\end{array}$ & $\begin{array}{l}\text { UK } \\
N=809\end{array}$ & ICECAP-O \\
\hline $\begin{array}{l}\text { Assessing quality of life in the elderly: A direct } \\
\text { comparison of the EQ-5D and AQOL [80] }\end{array}$ & $\begin{array}{l}\text { UK } \\
N=145\end{array}$ & $\begin{array}{l}\text { EQ-5D } \\
\text { AQOL }\end{array}$ \\
\hline $\begin{array}{l}\text { Cognition, daily living, and health-related } \\
\text { quality of life in 85-year-olds in Sweden [113] }\end{array}$ & $\begin{array}{l}\text { Sweden } \\
N=373\end{array}$ & EQ-5D \\
\hline $\begin{array}{l}\text { Developing capacities in aging studies in the } \\
\text { Middle East: Implementation of an Arabic } \\
\text { version of the CANE IV among community- }\end{array}$ & $\begin{array}{l}\text { Lebanon } \\
\mathrm{N}=322\end{array}$ & EQ-5D \\
\hline
\end{tabular}

version of the CANE IV among community- $\quad \mathrm{N}=322$

dwelling older adults in Lebanon [114]

Development and measurement properties of the self-assessment version of the INTERMED for the elderly to assess case complexity [115]

Development of the Japanese 15D instrument of health-related quality of life: verification of reliability and validity among elderly people [116]

Drug treatment in the elderly: an intervention in primary care to enhance prescription quality and quality of life [117]

Effect of preventive primary care outreach on health related quality of life among older adults at risk of functional decline: a randomized controlled trial [118]

Effects of risk-based multifactorial fall prevention on health-related quality of life among the community-dwelling aged: a randomized controlled trial [119]

Exercise in elderly patients with chronic heart failure in primary care: Effects on physical capacity and health-related quality of life [120]

Exploration of the association between quality of life, assessed by the EQ-5D and ICECAP-O, and falls risk, cognitive function and daily function, in older adults with mobility impairments

Falls and EQ-5D rated quality of life in community-dwelling seniors with concurrent chronic diseases: a cross-sectional study [121]

Falls-related self-efficacy is independently associated with quality-adjusted life years in older women [122]
Netherlands

$N=338$

Japan

$N=430$

Sweden

$N=150$

Canada

$N=719$

Finland

$N=591$

Sweden

$N=60$

Canada

$N=215$

Germany

$N=1792$

Canada

$\mathrm{N}=135$
EQ-5D and SF-36

EQ-5D

ICECAP-O

EQ-5D
The OPQOL-brief is of value in assessment of interventions where a rigorously tested, short measure is required

This study provides some early evidence for the construct validity of the ICECAP measure

A caring role is associated with a relatively high quality of life, that is comparable to that experienced by older people who categorize themselves in a non-caring role

Distribution of ICECAP-O values by electoral ward enabled the identification of areas of deprivation, although the associations were strong only for enjoyment and control

Although the AQoL appeared to have more favourable construct validity, the EQ-5D was easier to administer, had a higher completion rate, and appeared more sensitive to change

Cognitive impairment is associated with reduced quality of life

The Arabic version of the CANE appears acceptable in assessing needs of older adults in South Lebanon

This study supports the feasibility, reliability and validity of the IM-E-SA

The Japanese version of the 15D showed sufficient internal consistency and moderate repeatability

The intervention seems to have had no effect on quality of prescriptions or quality of life

The results of this study do not support adoption of this preventive primary care intervention for this target population of high risk older adults

Fall prevention produced positive effects on some dimensions of HRQL with men benefiting more than women

This study shows that exercise conducted in groups in primary care and in the patients' homes could be used in elderly patients with $\mathrm{CHF}$

Both the EQ-5D and ICECAP-O demonstrate associations with falls risk and general balance and mobility; however, only the ICECAP-O was associated with cognitive status among older adults with mobility impairments

The findings suggest that falls are negatively associated with EQ-5D rated quality of life independent of a variety of chronic diseases and conditions

Although falls-related self-efficacy was independently associated with QALYs, there may well be other factors not investigated, such as risk taking and psychological measures, which could account for some of the association 
Table 3 Classification of studies by context (Continued)

\begin{tabular}{|c|c|c|c|}
\hline \multirow{2}{*}{$\begin{array}{l}\text { Functional status and quality of life } 12 \text { months } \\
\text { after discharge from a medical ICU in healthy } \\
\text { elderly patients: a prospective observational } \\
\text { study [123] }\end{array}$} & Spain & \multirow[t]{2}{*}{ EQ-5D } & \multirow{2}{*}{$\begin{array}{l}\text { The survival rate of elderly medical patients } \\
12 \text { months after discharge from the ICU is low } \\
\text { although functional status and quality of life } \\
\text { remained similar to baseline in most of the } \\
\text { survivors }\end{array}$} \\
\hline & $N=112$ & & \\
\hline \multirow{2}{*}{$\begin{array}{l}\text { Happiness, subjective and objective oral health } \\
\text { status, and oral health behaviors among Korean } \\
\text { elders [124] }\end{array}$} & Korea & \multirow[t]{2}{*}{$E Q-5 D$} & \multirow{2}{*}{$\begin{array}{l}\text { Oral impacts which might persistently affect } \\
\text { one's daily life need to be considered in } \\
\text { designing and delivering public services } \\
\text { aimed to promote people's happiness }\end{array}$} \\
\hline & $N=479$ & & \\
\hline \multirow[t]{2}{*}{$\begin{array}{l}\text { Health status of the advanced elderly in six } \\
\text { European countries: results from a representative } \\
\text { survey using EQ-5D and SF-12 [125] }\end{array}$} & $\begin{array}{l}\text { Belgium, France, Germany, } \\
\text { Italy, the Netherlands } \\
\text { and Spain }\end{array}$ & \multirow[t]{2}{*}{ EQ-5D and SF-12 } & \multirow[t]{2}{*}{$\begin{array}{l}\text { More than two thirds of the advanced elderly } \\
\text { report impairment of health status }\end{array}$} \\
\hline & $N=1659$ & & \\
\hline \multirow{2}{*}{$\begin{array}{l}\text { Health-related quality of life measurements in } \\
\text { elderly Canadians with osteoporosis compared } \\
\text { to other chronic medical conditions:a } \\
\text { population-based study from the Canadian } \\
\text { Multicentre OsteoporosisStudy (CaMos) [126] }\end{array}$} & Canada & \multirow[t]{2}{*}{ HUI3 } & \multirow{2}{*}{$\begin{array}{l}\text { The decrement in HUI3 score seen in } \\
\text { participants with osteoporosis was } \\
\text { comparable to that observed in other } \\
\text { chronic medical conditions, such as arthritis, } \\
\text { COPD, diabetes mellitus or heart disease }\end{array}$} \\
\hline & $N=4,550$ & & \\
\hline \multirow{2}{*}{$\begin{array}{l}\text { Impaired Health-Related Quality of Life in Elderly } \\
\text { Women is Associated With Multimorbidity: } \\
\text { Results From the Korean National Health and } \\
\text { Nutrition Examination Survey [127] }\end{array}$} & Korea & \multirow[t]{2}{*}{ EQ-5D } & \multirow{2}{*}{$\begin{array}{l}\text { Both the amount and pattern of chronic } \\
\text { diseases have been associated with quality } \\
\text { of life in elderly populations }\end{array}$} \\
\hline & $N=1419$ & & \\
\hline \multirow{2}{*}{$\begin{array}{l}\text { Independent contribution of overweight/obesity } \\
\text { and physical inactivity to lower health-related } \\
\text { quality of life in community-dwelling older } \\
\text { subjects [128] }\end{array}$} & Poland & \multirow[t]{2}{*}{ EQ-5D } & \multirow{2}{*}{$\begin{array}{l}\text { Overweight/obesity and sedentary lifestyle } \\
\text { are independent predictors of lower HRQL in } \\
\text { community-dwelling seniors aged 66-79 years }\end{array}$} \\
\hline & $N=300$ & & \\
\hline \multirow{2}{*}{$\begin{array}{l}\text { Long term effects of exercise training on } \\
\text { physical activity level and quality of life in } \\
\text { elderly coronary patients - a three- to six-year } \\
\text { follow-up [129] }\end{array}$} & USA & \multirow[t]{2}{*}{$E Q-5 D$} & \multirow{2}{*}{$\begin{array}{l}\text { Even a short period of supervised exercise } \\
\text { training has the potential to positively influence } \\
\text { physical activity level for as long as three to } \\
\text { six years }\end{array}$} \\
\hline & $N=93$ & & \\
\hline \multirow{2}{*}{$\begin{array}{l}\text { Measuring quality of life in older people: } \\
\text { reliability and validity of WHOQoL-OLD [130] }\end{array}$} & Australia & \multirow{2}{*}{$\begin{array}{l}\text { WHOQoL-Old } \\
\text { and SF-12 }\end{array}$} & \multirow{2}{*}{$\begin{array}{l}\text { Overall, the WHOQOL-OLD performed well on } \\
\text { tests of reliability and validity }\end{array}$} \\
\hline & $N=100$ & & \\
\hline \multirow{2}{*}{$\begin{array}{l}\text { Medication quality and quality of life in the } \\
\text { elderly, a cohort study [131] }\end{array}$} & Sweden & \multirow[t]{2}{*}{ EQ-5D } & \multirow{2}{*}{$\begin{array}{l}\text { This study has shown the validity of the basic } \\
\text { principle in prescribing: the more appropriate } \\
\text { medication the better quality of life }\end{array}$} \\
\hline & $N=150$ & & \\
\hline \multirow{2}{*}{$\begin{array}{l}\text { Metabolic syndrome and quality of life in the } \\
\text { elderly: age and gender differences [132] }\end{array}$} & Italy & \multirow[t]{2}{*}{ HUI3 } & \multirow{2}{*}{$\begin{array}{l}\text { MetS is not associated with worse HRQL in } \\
\text { community-dwelling elderly }\end{array}$} \\
\hline & $N=356$ & & \\
\hline \multirow{2}{*}{$\begin{array}{l}\text { Mobility Is a Key Predictor of Change in } \\
\text { Well-Being Among Older Adults Who Experience } \\
\text { Falls: Evidence From the Vancouver Falls } \\
\text { Prevention Clinic Cohort [133] }\end{array}$} & Canada & ICECAP-O & We found that 2 valid and reliable measures \\
\hline & $N=244$ & & changes in well-being over time \\
\hline Mortality in healthy elderly patients after ICU & Spain & EQ-5D & Healthy elderly non-elective medical patients \\
\hline & $N=230$ & & $\begin{array}{l}\text { admitted to the } \mathrm{IC} \text { have a high mortality } \\
\text { rate related to premorbid quality of life }\end{array}$ \\
\hline Multifactorial Intervention to Reduce Falls in & Netherlands & EQ-5D and SF-12 & This multifactorial fall-prevention program \\
\hline Randomized Controlled Trial [135] & $N=217$ & & $\begin{array}{l}\text { does not reduce falls in high-risk, cognitively } \\
\text { intact older persons. }\end{array}$ \\
\hline Multi-morbidity and health-related quality of & Germany & EQ-5D & Multi-morbidity caused greater impairments \\
\hline German KORA-Age study [136] & $N=4565$ & & $\begin{array}{l}\text { In HRQL than could be expected from gIven } \\
\text { conditions individually/separately }\end{array}$ \\
\hline Pain, Medication Use, and Health-Related & USA & $E Q-5 D$ & Older persons with PHN experience \\
\hline $\begin{array}{l}\text { Neuralgia: Results From a Population-Based } \\
\text { Survey [137] }\end{array}$ & $N=385$ & & $\begin{array}{l}\text { longstanding, severe, and debillitatıng pain and } \\
\text { poor health-related quality of life }\end{array}$ \\
\hline $\begin{array}{l}\text { Perceived Participation and Health-Related } \\
\text { Ouality of Life in } 85 \text { Year Olds in Sweden [138] }\end{array}$ & Sweden & $E Q-5 D$ & $\begin{array}{l}\text { Sufficient participation was positively associated } \\
\text { with higher health-related quality of life and }\end{array}$ \\
\hline & $N=380$ & & $\begin{array}{l}\text { facilitating participation is an area of interest } \\
\text { for occupational therapists }\end{array}$ \\
\hline
\end{tabular}


Table 3 Classification of studies by context (Continued)

\begin{tabular}{|c|c|c|c|}
\hline \multirow{2}{*}{$\begin{array}{l}\text { Physical activity as a mediator of the impact of } \\
\text { chronic conditions on quality of life in older } \\
\text { adults [139] }\end{array}$} & Canada & \multirow[t]{2}{*}{ HUI3 } & \multirow{2}{*}{$\begin{array}{l}\text { Physical activity partially mediates the impact } \\
\text { of chronic conditions on quality of life }\end{array}$} \\
\hline & $N=22,432$ & & \\
\hline \multirow{2}{*}{$\begin{array}{l}\text { Physical function and perceived quality of life } \\
\text { in older persons [140] }\end{array}$} & Italy & \multirow[t]{2}{*}{ EQ-5D } & \multirow{2}{*}{$\begin{array}{l}\text { Physical function influences quality of life in } \\
\text { older persons }\end{array}$} \\
\hline & $N=73$ & & \\
\hline \multirow{2}{*}{$\begin{array}{l}\text { Potentially Inappropriate Drug Use and } \\
\text { Health-Related Quality of Life in the Elderly [141] }\end{array}$} & USA & EQ-5D & \multirow{2}{*}{$\begin{array}{l}\text { The results supported others showing that a } \\
\text { significant proportion of the elderly receive } \\
\text { care that is potentially harmful and not } \\
\text { supported by evidence-based practice }\end{array}$} \\
\hline & $N=444$ & SF-12 & \\
\hline \multirow{2}{*}{$\begin{array}{l}\text { Potentially inappropriate prescribing and } \\
\text { adverse health outcomes in community } \\
\text { dwelling older patients [142] }\end{array}$} & Ireland & \multirow[t]{2}{*}{ EQ-5D } & \multirow{2}{*}{$\begin{array}{l}\text { Reducing PIP in primary care may help lower } \\
\text { the burden of ADEs, its associated health care } \\
\text { use and costs and enhance quality of life in } \\
\text { older patients }\end{array}$} \\
\hline & $N=931$ & & \\
\hline \multirow{2}{*}{$\begin{array}{l}\text { Psychological approach to successful ageing } \\
\text { predicts future quality of life in older adults [143] }\end{array}$} & UK & \multirow[t]{2}{*}{ OPQOL } & \multirow{2}{*}{$\begin{array}{l}\text { Successful ageing is not only about the } \\
\text { maintenance of health, but about maximising } \\
\text { one's psychological resources, namely } \\
\text { self-efficacy and resilience }\end{array}$} \\
\hline & $N=287$ & & \\
\hline \multirow{2}{*}{$\begin{array}{l}\text { Psychometric evaluation of the Korean version } \\
\text { of the Self-Efficacy for Exercise Scale for older } \\
\text { adults [144] }\end{array}$} & South Korea & \multirow[t]{2}{*}{ EQ-5D } & \multirow{2}{*}{$\begin{array}{l}\text { The SEE-K appears to have satisfactory validity } \\
\text { and reliability among older adults in South Korea }\end{array}$} \\
\hline & $N=212$ & & \\
\hline \multirow{2}{*}{$\begin{array}{l}\text { Quality of life amongst older Brazilians: A } \\
\text { cross-cultural validation of the CASP-19 into } \\
\text { Brazilian-Portuguese [145] }\end{array}$} & Brazil & \multirow[t]{2}{*}{ CASP-19 } & \multirow{2}{*}{$\begin{array}{l}\text { In this small exploratory study the CASP-19 } \\
\text { Brazil demonstrated good psychometric } \\
\text { properties }\end{array}$} \\
\hline & $N=87$ & & \\
\hline \multirow{2}{*}{$\begin{array}{l}\text { Quality of life and related factors: a questionnaire } \\
\text { survey of older people living alone in Mainland } \\
\text { China [146] }\end{array}$} & China & \multirow[t]{2}{*}{ OPQOL } & \multirow{2}{*}{$\begin{array}{l}\text { his study identified nine factors influencing } \\
\text { the quality of life of older people living alone } \\
\text { in Mainland China }\end{array}$} \\
\hline & $N=521$ & & \\
\hline \multirow{2}{*}{$\begin{array}{l}\text { Quality of life in older outpatients living alone } \\
\text { in the community in Italy [147] }\end{array}$} & Italy & \multirow[t]{2}{*}{ OPQOL } & \multirow{2}{*}{$\begin{array}{l}\text { Depression, having no caregiver and having } \\
\text { never been married could provide a valuable } \\
\text { means of identifying older people living alone } \\
\text { who are at greater risk of a poor quality of life }\end{array}$} \\
\hline & $N=239$ & & \\
\hline \multirow{2}{*}{$\begin{array}{l}\text { Quality of life related to fear of falling and hip } \\
\text { fracture in older women: A time trade off } \\
\text { study [148] }\end{array}$} & Australia & \multirow[t]{2}{*}{ EQ-5D } & \multirow{2}{*}{$\begin{array}{l}\text { Among older women who have exceeded } \\
\text { average life expectancy, quality of life is } \\
\text { profoundly threatened by falls and hip fractures }\end{array}$} \\
\hline & $N=194$ & & \\
\hline Quality of well-being in older people with & USA & QWB & The QWB appears to be a useful and sensitive \\
\hline & $N=363$ & & $\begin{array}{l}\text { generic, utility-based measure of } \mathrm{HRQL} \text { in } \\
\text { people with OA }\end{array}$ \\
\hline Risk of malnutrition and health-related quality & Norway & EQ-5D & HRQL was significantly reduced in elderly men \\
\hline $\begin{array}{l}\text { of life in community-living elderly men and } \\
\text { women: The Troms } \varnothing \text { study [150] }\end{array}$ & $N=3286$ & & \\
\hline SF-6D and EQ-5D result in widely divergent & USA & EQ-5D and SF-6D & The incremental QALYs estimated from the \\
\hline $\begin{array}{l}\text { incremental cost-effectiveness ratios in a } \\
\text { clinical trial of older women: implications for } \\
\text { health policy decisions [151] }\end{array}$ & $N=155$ & & $\begin{array}{l}\text { SF-6D were two- to threefold greater than } \\
\text { those estimated from the EQ-5D }\end{array}$ \\
\hline Sleep Apnea and Health-Related Quality of & USA & QWB and SF-36 & Sleep disturbances may impact daily living and \\
\hline & $N=70$ & & \\
\hline Societal Consequences of Falls in the Older & Netherlands & EQ-5D & Fall-related injuries are age and gender related, \\
\hline $\begin{array}{l}\text { Population: Injurles, Healthcare Costs, and } \\
\text { Long-Term Reduced quality of life [153] }\end{array}$ & $N=668$ & & $\begin{array}{l}\text { leading to high healthcare costs, and } \\
\text { long-term reduced quality of life }\end{array}$ \\
\hline Socioeconomic status and health-related & Canada and USA & HUI3 & In the elderly population, $\mathrm{HRQL}$ was significantly \\
\hline $\begin{array}{l}\text { from the Joint Canada/United States } \\
\text { Survey of Health [154] }\end{array}$ & $N=1906$ & & $\begin{array}{l}\text { United States but not in Canada, controlling for } \\
\text { socio-demographic and health indicators }\end{array}$ \\
\hline The Health Consequences of Peripheral & USA & HUI3 & PNDs of undetermined cause, found in older \\
\hline $\begin{array}{l}\text { Neurological Deficits in an Elderly Cohort: An } \\
\text { Oklahoma Physicians Resource-Research }\end{array}$ & $N=604$ & QWB & $\begin{array}{l}\text { patients on physical examination, appear to } \\
\text { be associated with greater morbidity and }\end{array}$ \\
\hline Network Study [155] & & SF-36 & mortality \\
\hline $\begin{array}{l}\text { The health-related quality of life and cost } \\
\text { implications of falls in elderly women [156] }\end{array}$ & UK & EQ-5D & Interventions aimed at reducing fear of falling \\
\hline & & & \\
\hline
\end{tabular}


Table 3 Classification of studies by context (Continued)

The independent contribution of executive functions to health related quality of life in older women [157]

The influence of lower-extremity function in elderly individuals' quality of life: an analysis of the correlation between SPPB and EQ-5D [158]

The predictive value of self-rated health in the presence of subjective memory complaints on permanent nursing home placement in elderly primary care patients over 4-year follow-up [159]

The Psychometric Properties of the Older People's Quality of Life Questionnaire, Compared with the CASP-19 and the WHOQOL-OLD [89]

The Reliability and Validity of the Turkish Version of the World Health Organization Quality of Life Instrument-Older Adults Module (WHOQoL-Old) [160]

Which measure of quality of life performs best in older age? A comparison of the OPQOL, CASP-19 and WHOQOL-OLD [161]

Hospital and community-based older people

Economic evaluation alongside a single RCT of an integrative psychotherapeutic nursing home programme [162]

Influence of chronic cardiovascular disease and hospitalization due to this disease on quality of life of community-dwelling elderly [163]

The relationship between quality of life, health and care transition: an empirical comparison in an older post-acute population [164]

Elderly men's quality of life and lower urinary tract symptoms: an intricate relationship [165]

Quality of Life in Elderly Men With Aging Symptoms and Lower Urinary Tract Symptoms (LUTS) [166]

Hospital-based older people

Activities of Daily Living and Quality of Life of Elderly Patients After Elective Surgery for Gastric and Colorectal Cancers [167]

Cognitive, Functional, and quality of life Outcomes of Patients Aged 80 and Older Who Survived at Least 1 Year After Planned or Unplanned Surgery or Medical Intensive Care Treatment [168]

Costs and health outcomes of intermediate care: results from five UK case study sites [169]

$\begin{array}{lll}\text { UK } & \text { EQ-5D } & \begin{array}{l}\text { Our study highlights the specific executive } \\ \text { processes of set shifting and working memory } \\ \text { were independently associated with QALYs }\end{array} \\ N=135 & \text { EQ-5D } & \begin{array}{l}\text { An abnormal SPPB score was associated with } \\ \text { lower quality of life }\end{array} \\ N=422 & \end{array}$

Denmark

$N=757$

UK

$\mathrm{N}=$

OPQOL, CASP-19 The OPQOL has potential for use as a and WHOQOL-OLD multidimensional population surveillance instrument for use with older populations, or as an outcome measure of multisector policy

Turkey WHOQoL-Old

$N=527$

WHOQOL-Bref

The psychometric properties of the Turkish version of the WHOQOL-OLD were acceptable, indicating that the scale is reliable and valid for use with older Turkish adults ( $>65$ years)

OPQOL

CASP-19

WHOQOL-OLD

The OPQOL is of potential value in the outcome assessment of health and social interventions, which can have a multidimensional impact on people's lives

Netherlands

EQ-5D

No significant differences were found on QALYS

$N=168$

Poland

$N=300$

Australia

ICECAP-O

$\mathrm{N}=82$

EQ-5D

Brazil

$N=200$

WHOQoL-Old

WHOQOL-Bref

Brazil

$N=200$

WHOQoL-Old and WHOQOL-Bref

EQ-5D and SF-12

Japan

$\mathrm{N}=232$

Netherlands

EQ-5D

$N=204$
Hospitalization due to CVD results in more pronounced reduction in quality of life than CVD alone among community dwelling elderly

The correlations between the ICECAP-O, EQ-5D and CTM-3 instruments illustrate that capability is strongly and positively associated with health-related quality of life and the quality of care transitions

Moderate to severe LUTS are associated with worse quality of life ratings for almost all evaluation parameters

Moderate to severe ADAM and LUTS impact significantly all parameters of HRQL and generic quality of life proposed by the $\mathrm{WHO}$

Of the patients 75 years old or older who underwent elective surgery for gastric or colorectal cancer, only a few showed a protracted decline in ADL and most exhibited better quality of life after surgery

Health-related quality of life is similar to that of an age-matched general population in the long term

Our work suggests a need for the development and application of robust and reliable clinical criteria for admission to IC, and close co-operation between hospital and community service providers over selection of patients and targeting of IC and acute care services to meet defined clinical need 
Table 3 Classification of studies by context (Continued)

\begin{tabular}{|c|c|c|}
\hline \multirow{2}{*}{$\begin{array}{l}\text { Effectiveness of a video-based exercise } \\
\text { programme to reduce falls and improve HRQL } \\
\text { among older adults discharged from hospital: } \\
\text { a pilot randomized controlled trial [170] }\end{array}$} & Australia & EQ-5D \\
\hline & $N=53$ & $\begin{array}{l}\text { Comple } \\
\text { patient }\end{array}$ \\
\hline \multirow{2}{*}{$\begin{array}{l}\text { Health-Related Quality of Life After Transcatheter } \\
\text { Aortic Valve Implantation in Elderly Patients With } \\
\text { Severe Aortic Stenosis [171] }\end{array}$} & France & \multirow[t]{2}{*}{ EQ-5D } \\
\hline & $N=164$ & \\
\hline \multirow{2}{*}{$\begin{array}{l}\text { Health-related Quality of Life among hospitalized } \\
\text { older people awaiting residential aged care [172] }\end{array}$} & Australia & \multirow[t]{2}{*}{ AQoL } \\
\hline & $N=320$ & \\
\hline \multirow{2}{*}{$\begin{array}{l}\text { Long-term outcome of elderly patients requiring } \\
\text { intensive care admission for abdominal } \\
\text { pathologies: survival and quality of life [173] }\end{array}$} & Switzerland & EQ-5D \\
\hline & $N=36$ & SF-36 \\
\hline \multirow{2}{*}{$\begin{array}{l}\text { Multicomponent Geriatric Intervention for } \\
\text { Elderly Inpatients With Delirium: Effects on } \\
\text { Costs and Health-Related Quality of Life [174] }\end{array}$} & Finland & \multirow[t]{2}{*}{$15 \mathrm{D}$} \\
\hline & $N=174$ & \\
\hline \multirow{2}{*}{$\begin{array}{l}\text { Outcome and quality of life of elderly critically } \\
\text { ill patients: An Italian prospective observational }\end{array}$} & Italy & \multirow[t]{2}{*}{ EQ-5D } \\
\hline & $N=288$ & \\
\hline
\end{tabular}
study [175]

Outcomes among older people in a post-acute inpatient rehabilitation unit [176]

Patients undergoing sub-acute rehabilitation have accurate expectations of their health-related quality of life at discharge [177]

Proxy reporting of quality of life using the EQ-5D [178]

Quality of life after a sub-trochanteric fracture: A prospective cohort study on 87 elderly patients [179]

Self-reported quality of life in elderly patients with aggressive non-Hodgkin's lymphoma treated with CHOP chemotherapy [180]

Specialist geriatric medical assessment for patients discharged from hospital acute assessment units: randomised controlled trial [181]

Systematic comprehensive geriatric assessment in elderly patients on chronic dialysis: a cross-sectional comparative and feasibility study [182]

The correlation between patients, patient's relatives and healthcare professionals interpretation of quality of life - A prospective study [183]

EQ-5D

$-5 D$

Ireland

EQ-5D

$\mathrm{N}=32$

Australia

EQ-5D

$N=232$

Canada

EQ-5D

$\mathrm{N}=23$

Sweden

EQ-5D

$\mathrm{N}=87$

Netherlands

$\mathrm{N}=132$

UK

$N=433$

Netherlands

$\mathrm{N}=50$

UK

EQ-5D

$\mathrm{N}=22$

SF-36 completed by both atient and proxy

No significant difference in self-reported quality of life and falls prevention between groups; need for further research

In high-risk patients with severe aortic stenosis, quality of life and health status improved substantially at 1 month and improvement persisted 6 months after TAVI

People making the transition to residential aged care from hospital have very poor HRQL, but small gains in function seem to be related to improvement

A high mortality rate and a decrease in quality of life were observed in elderly patients with severe abdominal pathologies

Comprehensive geriatric intervention improved HRQL without increasing overall costs of care

One year after ICU discharge, medical and orthopedic patients had significantly more severe problems vis-a’ -vis mobility, self-care and activity than abdominal surgical patients and control population

EORTC OLO-C30

ICECAP-O

(patient and proxy)
Positive quality of life outcomes occurred in a range of measures in an older, frail inpatient rehabilitation population

Patients admitted for subacute in-hospital rehabilitation were able to anticipate their discharge health-related quality of life on the EQ-5D instrument with a moderate level of accuracy

Proxy EQ-5D responses, either for a specific point in time or for assessing change over time, may not be valid measures of self-reported quality of life among older medically-ill patients

A sub-trochanteric fracture in elderly patients had a substantial negative effect on both their short and long-term HRQL

In the elderly patients the quality of life was determined by two factors, i.e. aggressiveness of disease and toxicity of treatment applied to an at risk population of older people attending and being discharged from acute medical units had no effect on patients' outcomes or subsequent use of secondary care or long term care

Older patients on chronic dialysis have a high risk of functional decline

Preliminary results would suggest NOK have a better perception than healthcare professionals of patient's quality of life, however doctors may be better at predicting resuscitation decisions of patients
This specialist geriatric medical intervention 
Table 3 Classification of studies by context (Continued)

\begin{tabular}{|c|c|c|c|}
\hline \multirow{2}{*}{$\begin{array}{l}\text { Two perspectives of proxy reporting of } \\
\text { health-related quality of life using the } \\
\text { Euroqol-5D, an investigation of agreement [184] }\end{array}$} & Australia & \multirow{2}{*}{$\begin{array}{l}\text { EQ-5D (proxy } \\
\text { correspondent) }\end{array}$} & \multirow{2}{*}{$\begin{array}{l}\text { Clinician (physiotherapist) proxy-reports among } \\
\text { this population generally had good agreement } \\
\text { with patient self-report though this was affected } \\
\text { by proxy perspective, patient cognition, and timing }\end{array}$} \\
\hline & $N=272$ & & \\
\hline \multirow{2}{*}{$\begin{array}{l}\text { Validation of the Charlson Comorbidity Index } \\
\text { in acutely admitted elderly patients [185] }\end{array}$} & Spain & \multirow[t]{2}{*}{ EQ-5D } & \multirow{2}{*}{$\begin{array}{l}\text { This study shows that an increased CCI predicts } \\
\text { both short and long term mortality adequately } \\
\text { but is not able to predict post-discharge functional } \\
\text { decline in acutely admitted elderly patients }\end{array}$} \\
\hline & $N=1313$ & & \\
\hline \multirow{2}{*}{$\begin{array}{l}\text { An investigation into the association between } \\
\text { nutritional status and quality of life in older } \\
\text { people admitted to hospital [186] }\end{array}$} & UK & EQ-5D & \multirow{2}{*}{$\begin{array}{l}\text { Malnutrition risk is linked to a poorer quality } \\
\text { of life in older people on admission to hospital }\end{array}$} \\
\hline & $N=149$ & SF-36 & \\
\hline \multirow{2}{*}{$\begin{array}{l}\text { Assessing Health State Utilities in Elderly } \\
\text { Patients at Cardiovascular Risk [187] }\end{array}$} & USA & \multirow[t]{2}{*}{ HUI3 } & \multirow{2}{*}{$\begin{array}{l}\text { In this large implementation of the HUl in } \\
\text { elderly patients, the instrument did not } \\
\text { detect any differences in estimated utilities } \\
\text { related to having a Ml }\end{array}$} \\
\hline & $N=4677$ & & \\
\hline \multirow{2}{*}{$\begin{array}{l}\text { Femoral neck fractures in the elderly: Functional } \\
\text { outcome and quality of life according to } \\
\text { EuroQol [188] }\end{array}$} & Sweden & \multirow[t]{2}{*}{$E Q-5 D$} & \multirow{2}{*}{$\begin{array}{l}\text { Changes in the quality of life may be useful } \\
\text { to identify patients who might benefit from } \\
\text { reoperation, i.e. arthroplasty }\end{array}$} \\
\hline & $N=90$ & & \\
\hline \multirow{2}{*}{$\begin{array}{l}\text { Health-related quality of life and psychological } \\
\text { well-being in elderly patients with } \\
\text { haemophilia [189] }\end{array}$} & Italy & \multirow{2}{*}{$\begin{array}{l}\text { WHOQoL-Old } \\
\text { EQ-VAS and } \\
\text { WHOQOL-BREF }\end{array}$} & \multirow{2}{*}{$\begin{array}{l}\text { Compared to age-matched controls elderly } \\
\text { patients with haemophilia had an impaired } \\
\text { HRQL in association with their health status }\end{array}$} \\
\hline & $N=82$ & & \\
\hline \multirow{2}{*}{$\begin{array}{l}\text { Health-related quality of life in elderly patients } \\
\text { with familial hypercholesterolemia [190] }\end{array}$} & Sweden & \multirow[t]{2}{*}{$15 D$ and SF-36 } & \multirow{2}{*}{$\begin{array}{l}\text { HRQL appears to be similar to that of } \\
\text { age-standardized controls in the general } \\
\text { population }\end{array}$} \\
\hline & $N=37$ & & \\
\hline \multirow{2}{*}{$\begin{array}{l}\text { Internal fixation compared with total hip } \\
\text { replacement for displaced femoral neck fractures } \\
\text { in the elderly - A randomised, controlled } \\
\text { trial [191] }\end{array}$} & Sweden & \multirow[t]{2}{*}{ EQ-5D } & \multirow{2}{*}{$\begin{array}{l}\text { The results of our study strongly suggest } \\
\text { that THR provides a better outcome than IF } \\
\text { for elderly, relatively healthy, lucid patients } \\
\text { with a displaced fracture of the femoral neck }\end{array}$} \\
\hline & $N=102$ & & \\
\hline \multirow{2}{*}{$\begin{array}{l}\text { Predictors of Improvement in Health-Related } \\
\text { Quality of Life Among Elderly Patients With } \\
\text { Depression [192] }\end{array}$} & USA & \multirow[t]{2}{*}{ MOS-6 (SF-6D) } & \multirow{2}{*}{$\begin{array}{l}\text { Severity of depressive symptoms at baseline } \\
\text { was predictive of failure to improve HRQL }\end{array}$} \\
\hline & $N=100$ & & \\
\hline \multirow{2}{*}{$\begin{array}{l}\text { Quality of life (QOL) among community } \\
\text { dwelling older people in Taiwan measured by } \\
\text { the CASP-19, an index to capture quality of life } \\
\text { in old age [193] }\end{array}$} & Taiwan & \multirow{2}{*}{$\begin{array}{l}\text { CASP-19 and } \\
\text { CASP-12 }\end{array}$} & \multirow{2}{*}{$\begin{array}{l}\text { There was an inverse relationship between } \\
\text { the CASP total scores and frailty, chronic } \\
\text { diseases, depressive disorders, living alone } \\
\text { and fall events in the past } 12 \text { months }\end{array}$} \\
\hline & $N=699$ & & \\
\hline \multirow{2}{*}{$\begin{array}{l}\text { Quality of life related to fracture displacement } \\
\text { among elderly patients with femoral neck } \\
\text { fractures treated with internal fixation [194] }\end{array}$} & Sweden & EQ-5D & The rate of fracture healing complications \\
\hline & $N=90$ & & $\begin{array}{l}\text { fractures was high, and even in patients with } \\
\text { uneventfully healed fractures, there was a } \\
\text { substantial decrease in the quality of life }\end{array}$ \\
\hline Responsiveness of the EuroQol (EQ 5-D) and & Sweden & EQ-5D & The results showed high responsiveness for \\
\hline femoral neck fractures [195] & $N=110$ & SF-36 & $\begin{array}{l}\text { both instruments are suitable for use as } \\
\text { outcome measures in clinical trials in elderly } \\
\text { hip fracture patients }\end{array}$ \\
\hline The Importance of Acuity, Stereopsis, and & UK & $E Q-5 D$ & Acuity, stereopsis, and contrast sensitivity each \\
\hline $\begin{array}{l}\text { Contrast SensitIvity for Health-Related Quality } \\
\text { of Life in Elderly Women with Cataracts [196] }\end{array}$ & $N=306$ & & $\begin{array}{l}\text { contributed to quality of life, across a range of } \\
\text { measures, in elderly women with cataract }\end{array}$ \\
\hline All settings & & & \\
\hline Whose Quality of Life Is It Anyway? The Validity & UK & EQ-5D & The QoL-AD has very good psychometric \\
\hline $\begin{array}{l}\text { and Rellability of the Quality of Life-Alzneimer's } \\
\text { Disease (QoL-AD) Scale [25] }\end{array}$ & $N=261$ & & with a wide range of severity of dementia \\
\hline Quality of life in dementia - A one-year & UK & $E Q-5 D$ & The main finding of this study is that people \\
\hline TOl & $N=60$ & & $\begin{array}{l}\text { With demenetı do not perceive that their } \\
\text { quality of life declined over a period of one-year }\end{array}$ \\
\hline Valuation studies & & & \\
\hline Valuing the ICECAP capability index for & UK & ICECAP-O & Values that were estimated are feasible for use \\
\hline$[12]$ & $N=19$ & & $\begin{array}{l}\text { measure the impact of health and social } \\
\text { care interventions }\end{array}$ \\
\hline
\end{tabular}




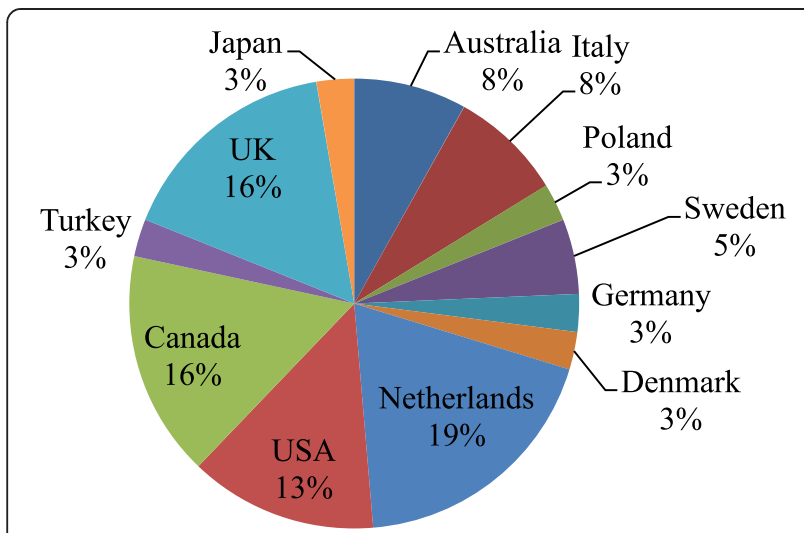

Fig. 2 Geographical distribution of studies

translations and scoring algorithms from several cultures and countries worldwide and its recommended use for the economic evaluation of new technologies by the National Institute for Health and Care Excellence (NICE) in the UK [65]. The ICECAP-O, CASP-19, OPQOL and ASCOT are all relatively newer instruments developed and validated in the UK. NICE recommends the ASCOT as the preferred measure for outcomes in social care and the ICECAP-O where outcomes in terms of capabilities are to be measured [65].

Five studies explicitly measured quality of life at more than one time point allowing some assessment of the sensitivity to change over time to be made $[24,45,51,63,64]$. Absolute changes in utility scores ranged from 0.003 to 0.21 based on 6-18 month follow-up periods. There is no consensus in the literature about what the minimal important difference (MID) should be (i.e. values range from 0.03 [66-68] to 0.074 [69] for changes in EQ-5D [64] and HUI3 utilities [45]). Some of the changes in quality of life reported upon in these studies were larger than the MID value reported in the literature (0.03). However, Drummond [66] indicates that if outcomes based on preference-based measures are to be used to influence resource allocation decisions, it is the difference in cost-effectiveness, such as the incremental

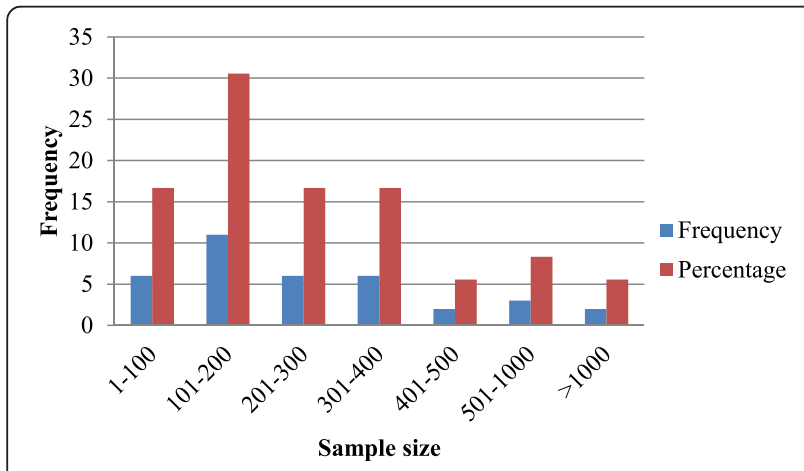

Fig. 3 Sample size distribution
Table 4 Instruments used in the identified studies

\begin{tabular}{llll}
\hline Instruments used & \multicolumn{2}{l}{ Number of studies } & \\
\cline { 2 - 4 } Instrument & $\begin{array}{l}\text { Community aged care } \\
\text { (Community dependent) }\end{array}$ & $\begin{array}{l}\text { Residential } \\
\text { aged care }\end{array}$ & Total \\
\hline EQ-5D & 10 & 6 & 16 \\
ASCOT & 3 & 1 & 4 \\
HUI2/3 & 4 & & 4 \\
EQ-5D + ASCOT & 1 & & 1 \\
EQ-5D + QWB & 1 & & 1 \\
EQ-5D + QWB + HUI3 & 1 & 2 & 1 \\
EQ-5D + ASCOT + ICECAP-O O & 2 & & 2 \\
EQ-5D + ICECAP-O & 1 & 1 & 1 \\
CASP-12/19 & 1 & 10 & 36 \\
OPQOL & 2 & & 2 \\
WHOQOL-OLD & & & 1 \\
Total & 26 &
\end{tabular}

cost per QALY, rather than the change in quality of life that is important. This therefore means that within an economic evaluation framework it is important to consider changes in quality of life in addition to the cost of bringing about such changes [66].

\section{Discussion}

In considering the suitability of instruments for use in evaluating interventions in the aged care sector, it's important to consider the aspects of quality of life that are most important to older people and to assess the ability (or otherwise) of each instrument to capture these aspects within the framework of economic evaluation.

This review has highlighted the multi-dimensional nature of quality of life for older people. Key elements of quality of life amongst community living dependent older people include physical and cognitive functioning [32, 34], independence in activities of daily living [37, 47], social relationships [31-33, 47], absence of morbidity or health impairments $[32,33,51]$ and pyscho-social wellbeing $[32,38,51]$ as well as social connectedness and accessibility within the home and community $[36,47,50]$. In the residential aged care context on the other hand key contributing factors to quality of life include independence in activities of daily living, sense of dignity and physical freedom $[55,58,60,70]$, absence of morbidity or health impairments [58] and happiness coupled with social participation $[60,61]$.

These findings are consistent with arguments made by several commentators that social participation [71-73], health $[10,71,72]$, wealth [72-74], home and community environment [10,72-75], and independence or control over their life $[10,72,73]$ represent key dimensions for any assessment of quality of life in samples of community living dependent older people. In the residential 
Table 5 Frequency with which the different instruments were used

\begin{tabular}{|c|c|c|c|c|}
\hline Instrument & Community aged care & Residential aged care & Percentage & Comment \\
\hline \multicolumn{5}{|c|}{ Generic Preference based } \\
\hline EQ-5D & 16 & 7 & 51 & $\begin{array}{l}\text { Community: With ASCOT } n=1 \text {, With QWB } n=1 \text {, With } \mathrm{QWB}+\mathrm{HUI3} \\
\mathrm{n}=1 \text {, With ASCOT + ICECAP-O } n=2 \text {, With ICECAP-O } n=1 \\
\text { Residential: With ICECAP-O } n=1\end{array}$ \\
\hline ASCOT & 6 & 1 & 16 & Community: With EQ-5D $n=1$, With EQ-5D + ICECAP-O $n=2$ \\
\hline $\mathrm{HUI} 2 / 3$ & 5 & 0 & 11 & With EQ-5D + QWB $n=1$ \\
\hline QWB & 1 & & 2 & With EQ-5D + HUI3 n= 1 \\
\hline \multicolumn{5}{|c|}{ Older people specific preference based } \\
\hline ICECAP-O & 3 & 2 & 11 & $\begin{array}{l}\text { Community: With EQ-5D } n=1 \text {, With EQ-5D + ASCOT } n=2 \\
\text { Residential: With EQ-5D } n=1\end{array}$ \\
\hline \multicolumn{5}{|c|}{ Older people specific non preference based } \\
\hline OPQOL & 2 & 0 & 4 & \\
\hline CASP-12/CASP-19 & 1 & 0 & 2 & \\
\hline WHOQoL-Old & 0 & 1 & 2 & \\
\hline Total & 34 & 11 & 100 & \\
\hline
\end{tabular}

aged care context, important dimensions highlighted in the literature include social participation in family and leisure activities [76-78], independence [76-79], peace and contentment $[76,79]$, security $[77,79]$ and spiritual well-being [77, 78].

Generic preference based instruments assess respondents' level of physical functioning through domains such as mobility within the EQ-5D, 15D and HUI3 and independent living within the AQOL. Psychological and emotional wellbeing is accounted for by anxiety/depression on the EQ-5D and 15D, emotion on HUI3 and happiness and mental health of the AQOL. Relationships and family dimensions may be captured by the relationships domain of the AQOL-8D. However, the question remains as to whether these quality of life dimensions are interpreted in the same way by older people themselves. For example physical functioning in older people may not necessarily be linked solely to their levels of mobility but also to their ability to participate in meaningful activities that emphasise their dignity, independence and relevance to society or their significant relations $[58,71]$.

Of the preference based instruments identified by this review, the EQ-5D is relatively easy to administer and has a higher completion rate [49, 70, 80-82]. With consideration to respondent burden, the EQ-5D may be considered to have practical advantages as it is relatively brief with only 5 dimensions. The other generic preference based instruments have more dimensions and/or dimension levels as illustrated in Table 1 with several also having mixed response items which may be considered to impose an additional response burden. Research has however shown that the EQ-5D has higher ceiling effects when compared against other instruments such the SF-6D and this needs to be taken into account [49, 83, 84]. The recent development of the new five-level version of the EQ-5D may however minimize this ceiling effect $[85,86]$. Coast et al. [87] and Hulme [88] have advocated for interviewer help to complete the instrument when used among the very elderly and those with reduced cognitive function. In fact other researchers have used proxy respondents to apply the instrument to people with mild to moderate cognitive impairment $[38,42,63,70]$. As highlighted previously, the vast majority of preference based HRQOL instruments such as the EQ-5D were developed for application in a health care context and are narrowly focused on health status alone a dimension highlighted in both community and residential aged care contexts, but it may not be the most appropriate indicator for measuring quality of life in older people. Several researchers have argued that these instruments are unlikely to be appropriate for assessing the well-being of older people in an aged care context because broader quality of life dimensions are important in this context.

The ASCOT is a preference based measure designed to specifically measure social care related quality of life and captures dimensions of quality of life relevant to people receiving social care services [19]. The ASCOT necessarily takes a broader quality of life focus including dimensions such as dignity, safety, control over daily life and social participation which are important for older people in both community and residential aged care $[24,49]$. The ASCOT may therefore be considered a relevant instrument to apply when assessing quality of life in relation to service innovations in the aged care sector. 
The older person specific instruments identified by this review reflect quality of life in a broader sense and thereby tend to address the majority of key domains previously highlighted as important to older people.

The OPQOL may be considered to represent the most comprehensive older people specific instrument developed to date as it contains quality of life domains/dimensions identified as important for both community and residential aged care contexts and it incorporates both health status and broader quality of life domains [89-91]. However, the OPQOL currently has limited use in an economic evaluation framework because it is not preference based.

The ICECAP-O also encompasses quality of life dimensions that are relevant in both community and residential aged care contexts such as independence or control, security, social participation or attachment, and it has been validated for use in older people in the health and the aged care sectors in several European countries $[16,49,55,70,92]$. It is also notable that good construct validity has been reported for the ICECAP-O when used in older people with mild to moderate cognitive impairment, a significant cohort of older people in general $[24,55,70,93]$. The ICECAP-O is also preference based which potentially facilitates its use in economic evaluations. Some commentators have suggested that the ICECAP-O is not suitable for use in CUA because of its focus on capabilities which does not enable the calculation of QALYs [24, 94]. However, other commentators have indicated that the ICECAP-O may be used within the framework of economic evaluation, with a revised capability based methodology for capturing the benefits associated with new interventions and/or service innovations $[95,96]$.

Overall for both the community and residential aged care contexts it's important to emphasize the breadth of dimensions that affect older people's quality of life. Compared to the EQ-5D, although the ASCOT and ICECAP-O do not have a health dimension per se, they are more sensitive to change and are more associated with broader quality of life beyond health [24]. This review argues that the choice of instrument is determined by the objective of the intervention being assessed; the EQ-5D being preferred for interventions aimed at maintaining health while the ASCOT and ICECAP-O are preferred for interventions with broader benefits beyond health such as service delivery innovations in the aged care sector $[24,49,55]$.

A limitation of this study was that due to the heterogeneity of and the lack of adequate data from the studies included in our sample, it was not possible to conduct any meta-correlations or meta-regressions to empirically test whether the instruments used in the studies included in this review perform differently in various contexts.

\section{Conclusions}

This review has highlighted that for older people quality of life is a multi-dimensional concept, being defined by broader dimensions of quality of life in addition to health status. Older people typically derive wider quality of life benefits from service innovations in aged care that may or may not also have a positive impact upon health status. In order to reflect the multi-dimensionality of quality of life and to capture wider quality of life benefits within an economic evaluation framework the most appropriate quality of life instrument for application in the aged care sector is one that ideally measures not only health status and functional ability but also wider quality of life dimensions of importance to older people such as independence, psychological wellbeing, social relationships and social connectedness.

Currently no single instrument exists which is preference based and commensurate with the QALY scale (and therefore appropriate for application in economic evaluation) incorporating both health status and the broader elements of quality of life previously highlighted.

In the absence of a single ideal instrument for CUA to assess the cost effectiveness of service innovations in the aged care sector, this review recommends the use of a generic preference based instrument, the EQ-5D to obtain QALYs in combination with the ICECAP-O or the ASCOT to facilitate the measurement and valuation of broader quality of life benefits as defined by older people.

\section{Additional file}

Additional file 1: Medline search strategy. Database(s): Ovid

MEDLINE(R) In-Process \& Other Non-Indexed Citations and Ovid MEDLINE(R) 1946 to Present. (PDF 158 kb)

\section{Abbreviations}

15D: 15-Dimensions; AQOL: Assessment of quality of life; ASCOT: Adult Social Care Outcomes Toolkit; CASP-19: Control Autonomy Self-realization and Pleasure; CUA: Cost utility analysis; DCE: Discrete choice experiment; EQ-5D: EuroQol - 5 Dimensions; HRQL: Health related quality of life; HUI2: Health Utilities Index Mark2; HUI3: Health Utilities Index Mark3; ICECAP-O: ICEpop CAPability measure for Older people; NHP: Nottingham Health Profile; OPQOL: Older People's Quality of Life; QALYs: Quality adjusted life years; QWB: Quality of Wellbeing scale; SF-12: Short Form 12; SF-36: Short Form 36; SF-6D: Short Form 6 Dimensions; SG: Standard gamble; TTO: Time trade off; VAS: Visual analogue scale; WHOQoL-Bref: World Health Organisation Quality of Life brief instrument; WHOQoL-Old: World Health Organisation Quality of Life Instrument-Older Adults Module.

\section{Competing interests}

The authors declare that they have no competing interests.

\section{Authors' contributions}

JR was responsible for study conception. NBB developed the systematic review protocol, conducted the review and wrote the first draft of the manuscript. BK and JR contributed to the development of the review protocol and revised the manuscript. All authors have seen and approved the final manuscript. 


\section{Acknowledgements}

We would like to thank Ms Nikki May who helped with the database searches and acquisition of the data. We would also like to thank Associate Professor Emily Lancsar and participants at the $36^{\text {th }}$ Annual Australian Health Economics (AHES) conference in September 2014 for their helpful comments on a previous version of this paper. Ms Norma Bulamu is supported by a PhD scholarship from an Australian Research Council Linkage grant (LP110200079).

Received: 7 April 2015 Accepted: 22 October 2015

Published online: 09 November 2015

\section{References}

1. United Nations. Population ageing and sustainable development. In: Population Facts, Department of Economic and Social Affairs Population Division. 2014

2. Sangl J, Saliba D, Gifford DR, Hittle DF. Challenges in measuring nursing home and home health quality: lessons from the First National Healthcare Quality Report. Med Care. 2005;43:124-32.

3. Shekelle PG, MacLean CH, Morton SC, Wenger NS. Assessing Care of Vulnerable Elders: Methods for Developing Quality Indicators. Ann Intern Med. 2001;135:647-52.

4. Gasior K, Huber M, Lamura G, Lelkes O, Marin B, Rodrigues R, Schmidt A, Zólyomi E: Facts and Figures on Healthy Ageing and Long-term Care. (Rodrigues R, Huber M, Lamura G eds.). Vienna: European Centre for Social Welfare Policy and Research; 2012.

5. Secretary of State for Health: Caring for our future: reforming care and support. (Health Do ed. United Kingdom: The Stationery Office Limited; 2012.

6. Administration on Aging (AoA) [http://www.aoa.gov/].

7. Department of Health and Ageing- Australian Government. Living longer. Living better: aged care reform package. Canberra: Department of Health and Ageing, Australian Government; 2012.

8. Felce D, Perry J. Quality of life: its definition and measurement. Res Dev Disabil. 1995;16:51-74.

9. WHOQOL GROUP. Measuring quality of life: the development of the World Health Organization Quality of Life Instrument (WHOQoL). Geneva: World Health Organization; 1993.

10. Milte CM, Walker R, Luszcz MA, Lancsar E, Kaambwa B, Ratcliffe J: How important is health status in defining quality of life for older people? an exploratory study of the views of older South Australians. Appl Health Econ Health Policy 2013, 12.

11. Davis JC, Liu-Ambrose T, Richardson CG, Bryan S. A comparison of the ICECAP-O with EQ-5D in a falls prevention clinical setting: are they complements or substitutes? Qual Life Res. 2013;22:969-77.

12. Coast J, Flynn TN, Natarajan L, Sproston K, Lewis J, Louviere JJ, et al. Valuing the ICECAP capability index for older people. Soc Sci Med. 2008;67:874-82.

13. Grewal I, Lewis J, Flynn T, Brown J, Bond J, Coast J. Developing attributes for a generic quality of life measure for older people: Preferences or capabilities? Soc Sci Med. 2006;62:1891-901.

14. Hickey A, Barker M, McGee H, O'Boyle C. Measuring health-related quality of life in older patient populations: a review of current approaches. Pharmacoeconomics. 2005;23:971-93.

15. Makai P, Brouwer WBF, Koopmanschap MA, Stolk EA, Nieboer AP. Quality of life instruments for economic evaluations in health and social care for older people: A systematic review. Soc Sci Med. 2014;102:83-93.

16. Coast J, Peters TJ, Natarajan L, Sproston K, Flynn T. An assessment of the construct validity of the descriptive system for the ICECAP capability measure for older people. Qual Life Res. 2008;17:967-76.

17. Brazier J, Ratcliffe J, Salomon AJ, Tsuchiya A. Methods for obtaining health state values: generic preference based measures of health and the alternatives. In: Measuring and Valuing Health Benefits for Economic Evaluation. New York: Oxford University Press; 2007. p. 175-256.

18. Drummond FM, Sculpher JM, Torrance WG, O'brien JB, Stoddart LG. Multi-attribute health status classification systems with preference scores. In: Methods for the Economic Evaluation of Health Care Programs. Thirdth ed. New York: Oxford University Press; 2005a. p. 154-72.

19. Netten A, Burge P, Malley J, Potoglou D, Towers A. Outcomes of social care for adults: developing a preference weighted measure. Health Technol Assess. 2012;16:165.
20. Netten A, Beadle-Brown J, Caiels J, Forder J, Malley J, Smith N, et al. Adult Social Care Outcomes Toolkit v2.1: Main guidance. In: PSSRU Discussion Paper Personal Social Services Research Unit. Canterbury: University of Kent; 2011.

21. Bowling A. What things are important in people's lives? Soc Sci Med. 1995;41:1447-62.

22. Bowling A. The most important things in life. Comparisons between older and younger population age groups by gender. International Journal of Health Sciences. 1995;6:169-75.

23. Kalfoss M, Halvorsrud L. Important Issues to Quality of Life Among Norwegian Older Adults: An Exploratory Study. The Open Nursing Journal. 2009;3:45-55.

24. van Leeuwen KM, Bosmans JE, Jansen APD, Hoogendijk EO, van Tulder MW, van der Horst HE, et al. Comparing Measurement Properties of the EQ-5D-3L, ICECAP-O, and ASCOT in Frail Older Adults. Value in Health (Wiley-Blackwell). 2015;18:35-43.

25. Fassino S, Leombruni P, Abbate Daga G, Brustolin A, Rovera GG, Abris F. Quality of life in dependent older adults living at home. Arch Gerontol Geriatr. 2002;35:9-20.

26. Cohen J. A coefficient of agreement for nominal scales. Education and Psychological Measures. 1960;20:37-46.

27. Bowling AZG, Dykes J, Dowding LM, Evans O, Fleissig A, Banister D, et al. Let's ask them: a national survey of definitions of quality of life and its enhancement among people aged 65 and over. Int J Aging Hum Dev. 2003:56:269-306.

28. Moher D, Liberati A, Tetzlaff J, Altman DG, The PG. Preferred Reporting Items for Systematic Reviews and Meta-Analyses: The PRISMA Statement. PLoS Med. 2009;6, e1000097.

29. Landis JR, Koch GG. The measurement of observer agreement for categorical data. Biometrics. 1977;33:159-74.

30. Malley JN, Towers A-M, Netten AP, Brazier JE, Forder JE, Flynn T. An assessment of the construct validity of the ASCOT measure of social care-related quality of life with older people. Health and Quality of Life Outcomes. 2012;10:1-14.

31. Forder JE, Caiels J. Measuring the outcomes of long-term care. Soc Sci Med. 2011;73:1766-74

32. Borowiak E, Kostka T. Predictors of quality of life in older people living at home and in institutions. Aging Clin Exp Res. 2004;16:212-20.

33. Maxwell CJ, Kang J, Walker JD, Zhang JX, Hogan DB, Feeny DH, et al. Sex differences in the relative contribution of social and clinical factors to the Health Utilities Index Mark 2 measure of health-related quality of life in older home care clients. Health and Quality of Life Outcomes. 2009;7:80.

34. McPhail S, Lane P, Russell T, Brauer SG, Urry S, Jasiewicz J, et al. Telephone reliability of the Frenchay Activity Index and EQ-5D amongst older adults. Health and Quality of Life Outcomes. 2009;7:1-8.

35. Makai P, Koopmanschap MA, Brouwer WB, Nieboer AA. A validation of the ICECAP-O in a population of post-hospitalized older people in the Netherlands. Health and Quality of Life Outcomes. 2013;11:1-11.

36. van Leeuwen KM, Malley J, Bosmans JE, Jansen APD, Ostelo RW, van der Horst HE, et al. What can local authorities do to improve the social carerelated quality of life of older adults living at home? Evidence from the Adult Social Care Survey. Health \& Place. 2014;29:104-13.

37. Andersen C, Wittrup-Jensen K, Lolk A, Andersen K, Kragh-Sørensen P. Ability to perform activities of daily living is the main factor affecting quality of life in patients with dementia. Health and Quality of Life Outcomes. 2004;2:1-7.

38. Snow AL, Dani R, Souchek J, Sullivan G, Ashton CM, Kunik ME. Comorbid psychosocial symptoms and quality of life in patients with dementia. Am J Geriatr Psychiatr. 2005;13:393-401

39. Greene T, Camicioli R. Depressive Symptoms and Cognitive Status Affect Health-Related Quality of Life in Older Patients with Parkinson's Disease. J Am Geriatr Soc. 2007:55:1888-90.

40. Oremus M, Tarride JE, Clayton N, Canadian Willingness-to-Pay Study Group, Raina P. Health utility scores in Alzheimer's disease: differences based on calculation with American and Canadian preference weights. Value Health. 2014;17:77-83.

41. Kleiner-Fisman G, Stern MB, Fisman DN. Health-Related Quality of Life in Parkinson disease: Correlation between Health Utilities Index III and Unified Parkinson's Disease Rating Scale (UPDRS) in U.S. male veterans. Health and Quality of Life Outcomes. 2010;8:1-9.

42. Naglie G, Hogan DB, Krahn M, Black SE, Beattie BL, Patterson C, et al. Predictors of Family Caregiver Ratings of Patient Quality of Life in Alzheimer Disease: Cross-Sectional Results from the Canadian Alzheimer's Disease Quality of Life Study. Am J Geriatr Psychiatr. 2011;19:891-901. 
43. Naglie G, Hogan DB, Krahn M, Beattie BL, Black SE, MacKnight C, et al. Predictors of Patient Self-Ratings of Quality of Life in Alzheimer Disease: Cross-Sectional Results From the Canadian Alzheimer's Disease Quality of Life Study. Am J Geriatr Psychiatr. 2011;19:881-90.

44. Kunz S. Psychometric properties of the EQ-5D in a study of people with mild to moderate dementia. Qual Life Res. 2010;19:425-34.

45. Kavirajan H, Hay SRD, Vassar S, Vickrey BG. Responsiveness and construct validity of the health utilities index in patients with dementia. Med Care. 2009;47:651-61.

46. Schölzel-Dorenbos CJM, Arons AMM, Wammes JJG, Rikkert M, Krabbe PFM. Validation study of the prototype of a disease-specific index measure for health-related quality of life in dementia. Health and Quality of Life Outcomes. 2012;10:1-11.

47. Bilotta C, Bowling A, Case A, Nicolini P, Mauri S, Castelli M, et al. Dimensions and correlates of quality of life according to frailty status: a cross-sectional study on community-dwelling older adults referred to an outpatient geriatric service in Italy. Health and Quality of Life Outcomes. 2010;8:10.

48. van Leeuwen K, Bosmans J, Jansen A, Rand S, Towers A-M, Smith N, et al. Dutch translation and cross-cultural validation of the Adult Social Care Outcomes Toolkit (ASCOT). Health and Quality of Life Outcomes. 2015;13:1-13.

49. van Leeuwen KM, Jansen APD, Muntinga ME, Bosmans JE, Westerman MJ, van Tulder MW, et al. Exploration of the content validity and feasibility of the EQ-5D-3L, ICECAP-O and ASCOT in older adults. BMC Health Serv Res. 2015;15:1-10.

50. Theeke LA, Mallow J. Loneliness and Quality of Life in Chronically III Rural Older Adults. Am J Nurs. 2013;113:28-37.

51. Zhang JX, Walker JD, Wodchis WP, Hogan DB, Feeny DH, Maxwell CJ. Measuring health status and decline in at-risk seniors residing in the community using the Health Utilities Index Mark 2. Qual Life Res. 2006;15:1415-26.

52. Bilotta C, Bowling A, Nicolini P, Casè A, Pina G, Rossi S, et al. Older People's Quality of Life (OPQOL) scores and adverse health outcomes at a one-year follow-up. A prospective cohort study on older outpatients living in the community in Italy. Health and Quality of Life Outcomes. 2011a;9:1-10.

53. Bilotta C, Bergamaschini L, Spreafico S, Vergani C. Day care centre attendance and quality of life in depressed older adults living in the community. European Journal of Ageing. 2010;7:29-35.

54. Vahlberg B, Cederholm T, Lindmark B, Zetterberg L, Hellstrom K. Factors Related to Performance-Based Mobility and Self-reported Physical Activity in Individuals 1-3 Years after Stroke: A Cross-sectional Cohort Study. Journal of Stroke \& Cerebrovascular Diseases. 2013;22:E426-34.

55. Makai P, Brouwer WB, Koopmanschap MA, Nieboer AP. Capabilities and quality of life in Dutch psycho-geriatric nursing homes: an exploratory study using a proxy version of the ICECAP-O. Qual Life Res. 2012;21:801-12.

56. Yamanaka K, Kawano Y, Noguchi D, Nakaaki S, Watanabe N, Amano T, et al. Effects of cognitive stimulation therapy Japanese version (CST-J) for people with dementia: A single-blind, controlled clinical trial. Aging and Mental Health. 2013;17:579-86.

57. Wolfs C, Dirksen C, Kessels A, Willems D, Verhey F, Severens J. Performance of the EQ-5D and the EQ-5D+C in elderly patients with cognitive impairments. Health and Quality of Life Outcomes. 2007:5:1-10.

58. Sitoh YY, Lau TC, Zochling J, Schwarz J, Chen JS, March LM, et al. Determinants of health-related quality of life in institutionalised older persons in northern Sydney. Internal Medicine Journal. 2005;35:131-4.

59. Comans TA, Peel NM, Gray LC, Scuffham PA. Quality of life of older frail persons receiving a post-discharge program. Health Qual Life Outcomes. 2013;11:1477-7525.

60. Netten A, Trukeschitz B, Beadle-Brown J, Forder J, Towers AM, Welch E. Quality of life outcomes for residents and quality ratings of care homes: is there a relationship? Age \& Ageing. 2012;41:512-7.

61. Top M, Dikmetas E. Quality of life and attitudes to ageing in Turkish older adults at old people's homes. Health Expect. 2015;18:288-300.

62. Torma J, Winblad U, Saletti A, Cederholm T. Strategies to Implement Community Guidelines on Nutrition and their Long-term Clinical Effects in Nursing Home Residents. Journal of Nutrition Health \& Aging. 2015;19:70-6.

63. Devine A, Taylor SJC, Spencer A, Diaz-Ordaz K, Eldridge S, Underwood M. The agreement between proxy and self-completed EQ-5D for care home residents was better for index scores than individual domains. J Clin Epidemiol. 2014;67:1035-43.

64. Underwood M, Lamb S, Eldridge S, Sheehan B, Slowther A. Exercise for depression in care home residents: a randomised controlled trial with cost-effectiveness analysis (OPERA). Health Technol Assess. 2013;17:281.
65. NICE: The social care guidance manual. (Excellence NIfHaC ed. pp. 99; 2013:99.

66. Drummond M. Introducing Economic and Quality of Life Measurements into Clinical Studies. Ann Med. 2001;33:344-9.

67. Dobrez D, Cella D, Pickard AS, Lai J-S, Nickolov A. Estimation of Patient Preference-Based Utility Weights from the Functional Assessment of Cancer Therapy_General. Value Health. 2007;10:266-72.

68. Cheung Y-B, Thumboo J, Gao F, Ng G-Y, Pang G, Koo W-H, et al. Mapping the English and Chinese Versions of the Functional Assessment of Cancer Therapy-General to the EQ-5D Utility Index. Value Health. 2009;12:371-6.

69. Walters S, Brazier J. Comparison of the minimally important difference for two health state utility measures: EQ-5D and SF-6D. Qual Life Res. 2005; 14:1523-32

70. Makai P, Beckebans F, van Exel J, Brouwer WBF. Quality of Life of Nursing Home Residents with Dementia: Validation of the German Version of the ICECAP-O. PLoS One. 2014;9, e92016.

71. Nilsson M, Ekman S, Sarvimaki A. Ageing with joy or resigning to old age: older people's experiences of the quality of life in old age. Health Care in Later Life. 1998;3:94-110.

72. Gabriel Z, Bowling A. Quality of life from the perspectives of older people. Ageing Soc. 2004;24:675-91.

73. Levasseur M, St-Cyr Tribble D, Desrosiers J. Meaning of quality of life for older adults: importance of human functioning components. Arch Gerontol Geriatr. 2009;49:1.

74. Borglin G, Edberg A-K, Rahm Hallberg I. The experience of quality of life among older people. J Aging Stud. 2005;19:201-20.

75. Levasseur M, Desrosiers J, St-Cyr Tribble D. Do quality of life, participation and environment of older adults differ according to level of activity? Health Qual Life Outcomes. 2008;6:1477-7525.

76. Hall S, Opio D, Dodd RH, Higginson IJ. Assessing quality-of-life in older people in care homes. Age Ageing. 2011;40:507-12.

77. Kane RA. Long-term care and a good quality of life: bringing them close together. Gerontologist. 2001;41:293-304.

78. Tester S, Hubbard G, Downs M, MacDonald C, Murphy J. What does quality of life mean for frail residents? Nursing \& Residential Care. 2004;6:89-92.

79. Hjaltadóttir I, Gústafsdóttir M. Quality of life in nursing homes: perception of physically frail elderly residents. Scand J Caring Sci. 2007;21:48-55.

80. Holland R, Smith RD, Harvey I, Swift L, Lenaghan E. Assessing quality of life in the elderly: A direct comparison of the EQ-5D and AQoL. Health Econ. 2004; 13:793-805

81. Gerard K, Mehta R, Mullee M, Nicholson T, Roderick P. EQ-5D versus SF-6D in an older, chronically ill patient group. Applied Health Economics and Health Policy. 2004;3:91+.

82. Davis JC, Bryan S, McLeod R, Rogers J, Khan K, Liu-Ambrose T. Exploration of the association between quality of life, assessed by the EQ-5D and ICECAP-O, and falls risk, cognitive function and daily function, in older adults with mobility impairments. BMC Geriatr. 2012;12:1-7.

83. Brazier J, Roberts J, Tsuchiya A, Busschbach J. A comparison of the EQ-5D and SF-6D across seven patient groups. Health Econ. 2004;13:873-84.

84. Wu J, Han Y, Zhao F-L, Zhou J, Chen Z, Sun H. Validation and comparison of EuroQoL-5 dimension (EQ-5D) and Short Form-6 dimension (SF-6D) among stable angina patients. Health and Quality of Life Outcomes. 2014;12:1-11.

85. Janssen MF, Pickard AS, Golicki D, Gudex C, Niewada M, Scalone L, et al. Measurement properties of the EQ-5D-5L compared to the EQ-5D-3L across eight patient groups: a multi-country study. Qual Life Res. 2013;22:1717-27.

86. Janssen MF, Birnie E, Bonsel GJ. Quantification of the level descriptors for the standard EQ-5D three-level system and a five-level version according to two methods. Qual Life Res. 2008;17:463-73.

87. Coast J, Peters TJ, Richards SH, Gunnell DJ. Use of the EuroQoL among elderly acute care patients. Qual Life Res. 1998;7:1-10.

88. Hulme C, Long AF, Kneafsey R, Reid G. Using the EQ-5D to assess healthrelated quality of life in older people. Age Ageing. 2004;33:504-7.

89. Bowling A. The Psychometric Properties of the Older People's Quality of Life Questionnaire, Compared with the CASP-19 and the WHOQOL-OLD. Current Gerontology and Geriatrics Research. 2009;2009:12.

90. Bowling A, Banister D, Sutton S, Evans O, Windsor J. A multidimensional model of the quality of life in older age. Aging Ment Health. 2002;6:355-71.

91. Hendry F, McVittie C. Is quality of life a healthy concept? Measuring and understanding life experiences of older people. Qual Health Res. 2004;14:961-75. 
92. Flynn TN, Chan P, Coast J, Peters TJ. Assessing quality of life among British older people using the ICEPOP CAPability (ICECAP-O) measure. Appl Health Econ Health Policy. 2011;9:317-29.

93. Purser JL, Fillenbaum GG, Pieper CF, Wallace RB. Mild cognitive impairment and 10-year trajectories of disability in the lowa Established Populations for Epidemiologic Studies of the Elderly cohort. J Am Geriatr Soc. 2005;53:1966-72.

94. Rowen D, Brazier J, Van Hout B. A Comparison of Methods for Converting DCE Values onto the Full Health-Dead QALY Scale. Med Decis Mak. 2014;35:328-40.

95. Mitchell PM, Roberts TE, Barton PM, Coast J. Assessing sufficient capability: A new approach to economic evaluation. Soc Sci Med. 2015;139:71-9.

96. Cookson R. QALYs and the capability approach. Health Econ. 2005;14:817-29.

97. EuroQol Group: EQ-5D.

98. Horsman J, Furlong W, Feeny D, Torrance G. The Health Utilities Index (HUI): concepts, measurement properties and applications. Health and Quality of Life Outcomes. 2003;1:54.

99. Brazier J, Roberts J, Deverill M. The estimation of a preference-based measure of health from the SF-36. J Health Econ. 2002;21:271-92.

100. Assessment of Quality of Life - instruments [http://www.aqol.com.au/].

101. Brazier J, Ratcliffe J, Salomon AJ, Tsuchiya A. Measuring and Valuing Health Benefits for Economic Evaluation. New York: Oxford University Press; 2007c.

102. Sintonen $H$, Pekurinen $M$. A fifteen-dimensional measure of health-related quality of life (15D) and its applications. In: Walker S, Rosser R, editors. Quality of Life Assessment: Key Issues in the 1990s. Netherlands: Springer; 1993. p. 185-95.

103. SF-36.org: SF-36.org: A community for measuring health outcomes using SF tools.

104. Group WHOQOL. Development of the World Health Organization WHOQOL-BREF Quality of Life Assessment. Psychol Med. 1998;28:551-8.

105. Wiklund I. The Nottingham Health Profile-a measure of health-related quality of life. Scand J Prim Health Care Suppl. 1990;1:15-8.

106. Herdman M, Gudex C, Lloyd A, Janssen MF, Kind P, Parkin D, et al. Development and preliminary testing of the new five-level version of EQ-5D (EQ-5D-5L). Qual Life Res. 2011;20.

107. Hyde M, Wiggins RD, Higgs P, Blane DB. A measure of quality of life in early old age: The theory, development and properties of a needs satisfaction model (CASP-19). Aging and Mental Health. 2003;7:186-94.

108. Power M, Quinn K, Schmidt S. Development of the WHOQOL-old module. Qual Life Res. 2005;14:2197-214

109. Windle G, Edwards R, Burholt V. A concise alternative for researching health-related quality of life in older people. Quality in Ageing. 2004;5:13-24.

110. Roalfe AK, Bryant TL, Davies MH, Hackett TG, Saba S, Fletcher K, et al. A cross-sectional study of quality of life in an elderly population (75 years and over) with atrial fibrillation: secondary analysis of data from the Birmingham Atrial Fibrillation Treatment of the Aged study. Europace. 2012;14:1420-7.

111. Bowling A, Hankins M, Windle G, Bilotta C, Grant R. A short measure of quality of life in older age: The performance of the brief Older People's Quality of Life questionnaire (OPQOL-brief). Arch Gerontol Geriatr. 2013;56:181-7.

112. Ratcliffe J, Lester LH, Couzner L, Crotty M. An assessment of the relationship between informal caring and quality of life in older community-dwelling adults - more positives than negatives? Health \& Social Care in the Community. 2013;21:35-46.

113. Johansson MM, Marcusson J, Wressle E. Cognition, daily living, and health-related quality of life in 85-year-olds in Sweden. Neuropsychol Dev Cogn B Aging Neuropsychol Cogn. 2012;19:421-32.

114. AbiHabib LE, Chemaitelly HS, Jaalouk LY, Karam NE. Developing capacities in aging studies in the Middle East: Implementation of an Arabic version of the CANE IV among community-dwelling older adults in Lebanon. Aging \& Mental Health. 2011;15:605-17.

115. Peters LL, Boter H, Slaets JP, Buskens E. Development and measurement properties of the self assessment version of the INTERMED for the elderly to assess case complexity. J Psychosom Res. 2013;74:518-22.

116. Okamoto N, Hisashige A, Tanaka Y, Kurumatani N: Development of the Japanese 15D instrument of health-related quality of life: verification of reliability and validity among elderly people. PLoS ONE [Electronic Resource] 2013, 8.

117. Olsson IN, Runnamo R, Engfeldt P. Drug treatment in the elderly: an intervention in primary care to enhance prescription quality and quality of life. 2012.
118. Ploeg J, Brazil K, Hutchison B, Kaczorowski J, Dalby DM, Goldsmith CH, Furlong W: Effect of preventive primary care outreach on health related quality of life among older adults at risk of functional decline: randomised controlled trial. Bmj 1480, 340.

119. Vaapio S, Salminen M, Vahlberg T, Sjosten N, Isoaho R, Aarnio P, et al. Effects of risk-based multifactorial fall prevention on health-related quality of life among the community-dwelling aged: a randomized controlled trial. Health Qual Life Outcomes. 2007;5:20.

120. Pihl E, Cider Å, Strömberg A, Fridlund B, Mårtensson J. Exercise in Elderly Patients with Chronic Heart Failure in Primary Care: Effects on Physical Capacity and Health-Related Quality of Life. Eur J Cardiovasc Nurs. 2011;10:150-8.

121. Thiem U, Klaaßen-Mielke R, Trampisch U, Moschny A, Pientka L, Hinrichs T. Falls and EQ-5D rated quality of life in community-dwelling seniors with concurrent chronic diseases: a cross-sectional study. Health and Quality of Life Outcomes. 2014;12:2

122. Davis JC, Marra CA, Liu-Ambrose TY. Falls-related self-efficacy is independently associated with quality-adjusted life years in older women. Age Ageing. 2011;40:340-6.

123. Sacanella E, Pérez-Castejón J, Nicolás J, Masanés F, Navarro M, Castro P, et al. Functional status and quality of life 12 months after discharge from a medical ICU in healthy elderly patients: a prospective observational study. Crit Care. 2011;15:1-9.

124. Yoon HS, Kim HY, Patton LL, Chun JH, Bae KH, Lee MO. Happiness, subjective and objective oral health status, and oral health behaviors among Korean elders. Community Dent Oral Epidemiol. 2013;41:459-65.

125. Konig HH, Heider D, Lehnert T, Riedel-Heller SG, Angermeyer MC, Matschinger H, Vilagut G, Bruffaerts R, Haro JM, de Girolamo G, et al.: Health status of the advanced elderly in six European countries: results from a representative survey using EQ-5D and SF-12. Health \& Quality of Life Outcomes 2010, 8

126. Sawka AM, Thabane L, Papaioannou A, Gafni A, loannidis G, Papadimitropoulos EA, et al. Health-related quality of life measurements in elderly Canadians with osteoporosis compared to other chronic medical conditions: a population-based study from the Canadian Multicentre Osteoporosis Study (CaMos). Osteoporos Int. 2005;16:1836-40.

127. Kim Kl, Lee JH, Kim CH. Impaired Health-Related Quality of Life in Elderly Women is Associated With Multimorbidity: Results From the Korean National Health and Nutrition Examination Survey. Gender Medicine. 2012;9:309-18.

128. Kostka T, Bogus K. Independent contribution of overweight/obesity and physical inactivity to lower health-related quality of life in community-dwelling older subjects. Zeitschrift Fur Gerontologie Und Geriatrie. 2007;40:43-51.

129. Hage C, Mattsson E, Ståhle A. Long term effects of exercise training on physical activity level and quality of life in elderly coronary patients - A three- to six-year follow-up. Physiother Res Int. 2003;8:13-22.

130. Peel NM, Bartlett HP, Marshall AL. Measuring quality of life in older people: reliability and validity of WHOQOL-OLD. Australasian Journal on Ageing. 2007;26:162-7.

131. Nordin Ol, Runnamo R, Engfeldt P: Medication quality and quality of life in the elderly, a cohort study. Health and Quality of Life Outcomes 2011, 9.

132. Laudisio A, Marzetti E, Antonica L, Pagano F, Vetrano DL, Bernabei $R$, et al. Metabolic syndrome and quality of life in the elderly: age and gender differences. Eur J Nutr. 2013;52:307-16.

133. Davis JC, Best JR, Bryan S, Li LC, Hsu CL, Gomez C, Vertes K, Liu-Ambrose T: Mobility Is a Key Predictor of Change in Well-Being Among Older Adults Who Experience Falls: Evidence From the Vancouver Falls Prevention Clinic Cohort. Archives of Physical Medicine and Rehabilitation 2015.

134. Sacanella E, Perez-Castejon JM, Nicolas JM, Masanes F, Navarro M, Castro P, et al. Mortality in healthy elderly patients after ICU admission. Intensive Care Med. 2009:35:550-5.

135. de Vries OJ, Peeters G, Elders PJM, Muller M, Knol DL, Danner SA, et al. Multifactorial Intervention to Reduce Falls in Older People at High Risk of Recurrent Falls A Randomized Controlled Trial. Arch Intern Med. 2010;170:1110-7.

136. Hunger $M$, Thorand B, Schunk M, Doring A, Menn P, Peters A, et al. Multimorbidity and health-related quality of life in the older population: results from the German KORA-age study. Health Qual Life Outcomes. 2011;9:1477-7525

137. Oster G, Harding G, Dukes E, Edelsberg J, Cleary PD. Pain, Medication Use, and Health-Related Quality of Life in Older Persons With Postherpetic Neuralgia: Results From a Population-Based Survey. The Journal of Pain. 2005;6:356-63. 
138. Lantz K, Marcusson J, Wressle E. Perceived Participation and Health-Related Quality of Life in 85 Year Olds in Sweden. Otjr-Occupation Participation and Health. 2012;32:117-25

139. Sawatzky R, Liu-Ambrose T, Miller WC, Marra CA. Physical activity as a mediator of the impact of chronic conditions on quality of life in older adults. Health Qual Life Outcomes. 2007;5:68.

140. Fusco O, Ferrini A, Santoro M, Lo Monaco MR, Gambassi G, Cesari M. Physical function and perceived quality of life in older persons. Aging Clin Exp Res. 2012;24:68-73

141. Franic DM, Jiang JZ. Potentially Inappropriate Drug Use and Health-Related Quality of Life in the Elderly. Pharmacotherapy: The Journal of Human Pharmacology and Drug Therapy. 2006;26:768-78.

142. Cahir C, Bennett K, Teljeur C, Fahey T. Potentially inappropriate prescribing and adverse health outcomes in community dwelling older patients. $\mathrm{Br}$ J Clin Pharmacol. 2014;77:201-10.

143. Bowling A, lliffe S. Psychological approach to successful ageing predicts future quality of life in older adults. Health and Quality of Life Outcomes. 2011;9:1-10

144. Choi M, Ahn S, Jung D: Psychometric evaluation of the Korean Version of the Self-Efficacy for Exercise Scale for older adults. Geriatric Nursing 2015

145. Lima FM, Hyde M, Chungkham HS, Correia C, Campos AS, Campos M, Novaes M, Laks J, Petribu K: Quality of life amongst older brazilians: A cross-cultural validation of the CASP-19 into brazilian-portuguese. PLOS ONE 2014, 9

146. Chen Y, Hicks A, While AE: Quality of life and related factors: a questionnaire survey of older people living alone in Mainland China. Quality of Life Research 2014

147. Bilotta C, Bowling A, Nicolini P, Casè A, Vergani C. Quality of life in older outpatients living alone in the community in Italy. Health \& Social Care in the Community. 2012;20:32-41.

148. Salkeld G, Cameron ID, Cumming RG, Easter S, et al. Quality of life related to fear of falling and hip fracture in older women: A time trade off study / Commentary. Br Med J. 2000;320:341-6.

149. GroessI EJ, Kaplan RM, Cronan TA. Quality of well-being in older people with osteoarthritis. Arthritis \& Rheumatism. 2003;49:23-8.

150. Kvamme J-M, Olsen JA, Florholmen J, Jacobsen BK. Risk of malnutrition and health-related quality of life in community-living elderly men and women: The Tromsø study. Qual Life Res. 2011:20:575-82.

151. Davis JC, Liu-Ambrose T, Khan KM, Robertson MC, Marra CA. SF-6D and EQ-5D result in widely divergent incremental cost-effectiveness ratios in a clinical trial of older women: implications for health policy decisions. Osteoporos Int. 2012;23:1849-57.

152. Stepnowsky C, Johnson S, Dimsdale J, Ancoli-Israel S. Sleep apnea and health-related quality of life in African-American elderly. Ann Behav Med. 2000:22:116-20.

153. Hartholt KA, van Beeck EF, Polinder S, van der Velde N, van Lieshout EM, Panneman MJ, et al. Societal consequences of falls in the older population: injuries, healthcare costs, and long-term reduced quality of life. J Trauma. 2011;71:748-53.

154. Huguet N, Kaplan MS, Feeny D. Socioeconomic status and health-related quality of life among elderly people: Results from the Joint Canada/United States Survey of Health. Soc Sci Med. 2008;66:803-10.

155. Mold JW, Lawler F, Roberts M. The Health Consequences of Peripheral Neurological Deficits in an Elderly Cohort: An Oklahoma Physicians Resource-Research Network Study. J Am Geriatr Soc. 2008:56:1259-64.

156. Iglesias CP, Manca A, Torgerson DJ. The health-related quality of life and cost implications of falls in elderly women. Osteoporos Int. 2009;20:869-78.

157. Davis JC, Marra CA, Najafzadeh M, Liu-Ambrose T. The independent contribution of executive functions to health related quality of life in older women. BMC Geriatr. 2010:10:1-8.

158. Oh B, Cho B, Choi HC, Son KY, Park SM, Chun S, et al. The influence of lower-extremity function in elderly individuals' quality of life (QOL): an analysis of the correlation between SPPB and EQ-5D. Archives of Gerontology \& Geriatrics. 2014;58:278-82.

159. Nielsen ABS, Siersma V, Waldemar G, Waldorff FB. The predictive value of self-rated health in the presence of subjective memory complaints on permanent nursing home placement in elderly primary care patients over 4-year follow-up. Age \& Ageing. 2014:43:50-7.

160. Eser S, Saatli G, Eser E, Baydur H, Fidaner C. The Reliability and Validity of the Turkish Version of the World Health Organization Quality of Life InstrumentOlder Adults Module (WHOQOL-Old). Turk Psikiyatri Dergisi. 2010;21:1-48.
161. Bowling A, Stenner P. Which measure of quality of life performs best in older age? A comparison of the OPQOL, CASP-19 and WHOQOL-OLD. J Epidemiol Community Health. 2011;65:273-80.

162. Hakkaart-van Roijen L, Bakker TJ, Al M, van der Lee J, Duivenvoorden HJ, Ribbe MW, Huijsman R: Economic evaluation alongside a single RCT of an integrative psychotherapeutic nursing home programme. BMC Health Services Research 2013, 13.

163. Borowiak E, Kostka T. Influence of chronic cardiovascular disease and hospitalisation due to this disease on quality of life of community-dwelling elderly. Qual Life Res. 2006:15:1281-9.

164. Couzner L, Ratcliffe J, Crotty M. The relationship between quality of life, health and care transition: an empirical comparison in an older post-acute population. Health and Quality of Life Outcomes. 2012;10:1-9.

165. Pintarelli VL, Perchon LF, Lorenzetti F, Toniolo Neto J, Dambros M. Elderly men's quality of life and lower urinary tract symptoms: an intricate relationship. Int Braz J Urol. 2011;37:758-65.

166. Perchon LF, Pintarelli VL, Bezerra E, Thiel M, Dambros M. Quality of life in elderly men with aging symptoms and lower urinary tract symptoms (LUTS). Neurourol Urodyn. 2011;30:515-9.

167. Amemiya T, Oda K, Ando M, Kawamura T, Kitagawa Y, Okawa Y, et al. Activities of daily living and quality of life of elderly patients after elective surgery for gastric and colorectal cancers. Ann Surg. 2007;246:222-8.

168. de Rooij SE, Govers AC, Korevaar JC, Giesbers AW, Levi M, de Jonge E. Cognitive, functional, and quality-of-life outcomes of patients aged 80 and older who survived at least 1 year after planned or unplanned surgery or medical intensive care treatment. J Am Geriatr Soc. 2008;56:816-22.

169. Kaambwa B, Bryan S, Barton P, Parker H, Martin G, Hewitt G, et al. Costs and health outcomes of intermediate care: results from five UK case study sites. Health \& Social Care in the Community. 2008;16:573-81.

170. Haines TP, Russell T, Brauer SG, Erwin S, Lane P, Urry S, et al. Effectiveness of a video-based exercise programme to reduce falls and improve health-related quality of life among older adults discharged from hospital: a pilot randomized controlled trial. Clin Rehabil. 2009;23:973-85.

171. Elmalem S, Dumonteil N, Marcheix B, Toulza O, Vellas B, Carrie D, et al. Health-Related Quality of Life After Transcatheter Aortic Valve Implantation in Elderly Patients With Severe Aortic Stenosis. Journal of the American Medical Directors Association. 2014;15:201-6.

172. Giles LC, Hawthorne G, Crotty M: Health-related Quality of Life among hospitalized older people awaiting residential aged care. Health and Quality of Life Outcomes 2009, 7.

173. Merlani P, Chenaud C, Mariotti N, Ricou B. Long-term outcome of elderly patients requiring intensive care admission for abdominal pathologies: survival and quality of life*. Acta Anaesthesiol Scand. 2007:51:530-7.

174. Pitkala KH, Laurila JV, Strandberg TE, Kautiainen H, Sintonen H, Tilvis RS. Multicomponent Geriatric Intervention for Elderly Inpatients With Delirium: Effects on Costs and Health-Related Quality of Life. The Journals of Gerontology. 2008;63A:56-61.

175. Pavoni V, Gianesello L, Paparella L, Buoninsegni LT, Mori E, Gori G. Outcome and quality of life of elderly critically ill patients: An Italian prospective observational study. Arch Gerontol Geriatr. 2012;54:e193-8.

176. Coleman SA, Cunningham CJ, Walsh JB, Coakley D, Harbison J, Casey M et al. Outcomes among older people in a post-acute inpatient rehabilitation unit. Disabil Rehabil. 2012;34:1333-8.

177. McPhail S, Haines T. Patients undergoing subacute rehabilitation have accurate expectations of their health-related quality of life at discharge. Health \& Quality of Life Outcomes. 2012;10.

178. Tamim H, McCusker J, Dendukuri N. Proxy reporting of quality of life using the EQ-5D. Med Care. 2002:40:1186-95.

179. Ekström W, Németh G, Samnegård E, Dalen N, Tidermark J. Quality of life after a subtrochanteric fracture: A prospective cohort study on 87 elderly patients. Injury. 2009;40:371-6.

180. Doorduijn J, Buijt I, van der Holt B, Steijaert M, Uyl-de Groot C, Sonneveld P. Self-reported quality of life in elderly patients with aggressive non-Hodgkin's lymphoma treated with CHOP chemotherapy. Eur J Haematol. 2005:75:116-23.

181. Edmans J, Bradshaw L, Franklin M, Gladman J, Conroy S. Specialist geriatric medical assessment for patients discharged from hospital acute assessment units: randomised controlled trial. Bmj-British Medical Journal. 2013;347:9.

182. Parlevliet JL, Hodac M, Buurman BM, Boeschoten EW, De Rooij SE: Systematic comprehensive geriatric assessment in elderly patients on chronic dialysis. European Geriatric Medicine Conference: 6th Congress of the EUGMS Dublin United Kingdom Conference Start 2010, 1. 
183. Jones LC, Sword J, Strain WD, Ostrowski C: The correlation between patients, patient's relatives and healthcare professionals interpretation of quality of life - A prospective study. European Geriatric Medicine Conference: 10th International Congress of the European Union Geriatric Medicine Society Geriatric Medicine Crossing Borders, EUGMS 2014, 5.

184. McPhail S, Beller E, Haines T. Two perspectives of proxy reporting of health-related quality of life using the euroqol-5D, an investigation of agreement. Med Care. 2008;46:1140-8.

185. Frenkel W, Jongerius E, Van Munster BC, Mandjes-Van Uitert M, De Rooij SE: Validation of the Charlson Comorbidity Index in acutely admitted elderly patients. European Geriatric Medicine Conference: 7th Congress of the EUGMS Malaga Spain Conference Start 2011, 2

186. Rasheed S, Woods RT. An investigation into the association between nutritional status and quality of life in older people admitted to hospital. J Hum Nutr Diet. 2014;27:142-51.

187. Winkelmayer WC, Benner JS, Glynn RJ, Schneeweiss S, Wang PS, Brookhart $\mathrm{M}$, et al. Assessing Health State Utilities in Elderly Patients at Cardiovascular Risk. Med Decis Mak. 2006;26:247-54.

188. Tidermark J, Zethraeus N, Svensson O, Törnkvist H, Ponzer S. Femoral neck fractures in the elderly: Functional outcome and quality of life according to EuroQol. Qual Life Res. 2002;11:473-81.

189. Von Mackensen S, Gringeri A, Siboni SM, Mannucci PM. Health-related quality of life and psychological well-being in elderly patients with haemophilia. Haemophilia. 2012;18:345-52.

190. Hyttinen L, Kekalainen $P$, Vuorio AF, Sintonen H, Strandberg TE. Healthrelated quality of life in elderly patients with familial hypercholesterolemia. Int J Technol Assess Health Care. 2008;24:228-34.

191. Tidermark J, Ponzer S, Svensson O, Soderqvist A, Tornkvist H. Internal fixation compared with total hip replacement for displaced femoral neck fractures in the elderly - A randomised, controlled trial. Journal of Bone and Joint Surgery-British Volume. 2003;85B:380-8.

192. Shmuely Y, Baumgarten M, Rovner B, Berlin J. Predictors of Improvement in Health-Related Quality of Life Among Elderly Patients With Depression. Int Psychogeriatr. 2001;13:63-73.

193. Wu TY, Chie WC, Kuo KL, Wong WK, Liu JP, Chiu ST, et al. Quality of life (QOL) among community dwelling older people in Taiwan measured by the CASP-19, an index to capture QOL in old age. Archives of Gerontology \& Geriatrics. 2013;57:143-50.

194. Tidermark J, Zethraeus N, Svensson O, Tornkvist H, Ponzer S. Quality of life related to fracture displacement among elderly patients with femoral neck fractures treated with internal fixation. 2002.

195. Tidermark J, Bergstrom G, Svensson O, Tornkvist H, Ponzer S. Responsiveness of the EuroQol (EQ 5-D) and the SF-36 in elderly patients with displaced femoral neck fractures. Qual Life Res. 2003;12:1069-79.

196. Datta S, Foss AJE, Grainge MJ, Gregson RM, Zaman A, Masud T, et al. The Importance of Acuity, Stereopsis, and Contrast Sensitivity for Health-Related Quality of Life in Elderly Women with Cataracts. Invest Ophthalmol Vis Sci. 2008:49:1-6.

\section{Submit your next manuscript to BioMed Central and take full advantage of:}

- Convenient online submission

- Thorough peer review

- No space constraints or color figure charges

- Immediate publication on acceptance

- Inclusion in PubMed, CAS, Scopus and Google Scholar

- Research which is freely available for redistribution 